\title{
On early antiquarians in Asia Minor to the start of the $19^{\text {th }}$ century
}

\author{
Terrance Michael Patrick DUGGAN*
}

Both the range of this subject and its time span are truly vast. ${ }^{1}$ This paper addresses a few of the issues concerning the activities of European antiquarians and the ancient Greek and Roman inscriptions of Asia Minor over the course of four hundred years from 1400 to 1800, touching upon five matters. Firstly, the collection and removal of antiquities including inscriptions by Europeans. Secondly, the varied functions of the visible ancient inscriptions for the Ottoman state and its inhabitants, both talismanic and therapeutic, and of the "non-literal reading" of an ancient inscription, distinct from the European antiquarian interest in the literal text of inscriptions, in establishing record of, and collections of the inscribed historical texts surviving from antiquity. Thirdly, the question of how safe a home was Europe for antiquities, including inscriptions and manuscripts that were brought from Asia Minor, and how much of scholarly importance that had survived was then lost in transit at sea and in Europe in wars and disasters? Fourthly, the problems with the transcriptions made by hand, the content of the record made and its accuracy. Was the inscription regarded simply as a text, prioritised as a text, or, was the text transcribed in its context including the epigraphic surface, its shape and relief carving, if any, its physical location if in situ, was it understood as forming a whole, and was it recorded as such? Were the letter forms, the number of lines, the different size of letters and words in an inscription, misspellings, etc., accurately noted or not? And, finally, the problems generated through the printed publication from the $16^{\text {th }} \mathrm{c}$. onwards of the transcriptions that had been made of inscriptions, in particular, those employing a standard font in publication for the study of inscriptions, not least impacting the understanding of orthography. Again, was it a matter of the antiquarian publishing just the text of an inscription, or the text within its context, to scale,

\footnotetext{
* Öğr. Gör. Terrance Michael Patrick Duggan, Mediterranean Civilisations Research Institute, Akdeniz University, Antalya, Turkey (tmpduggan@yahoo.com).

This contribution is the paper from the presentation given at the symposium on the "Epigraphies of Anatolia: their histories and their future”, 24-27 April 2018, The Koç University Suna \& İnan Kıraç Research Centre for Mediterranean Civilizations (AKMED), Antalya.

${ }^{1}$ Among the more important recent works to address this subject are: Cyriac of Ancona, Later Travels, Ed. And Trans. Edward W. Bodnar with Clive Foss, Harvard University Press, 2003, covering the 1440's which provides a broad picture of the quantity at this date of the visible remains of antiquity in the region; and, Michael Greenhalgh, From the Romans to the Railways: The Fate of Antiquities in Asia Minor, Brill, Leiden 2013, in part, associating the course of modernisation of the $19^{\text {th }} \mathrm{c}$. Ottoman state with the removal of antiquities, due to the development of improved transportation infrastructure facilitating their removal. See for comparisons, Michael Greenhalgh, Destruction of Cultural Heritage in 19th-century France: Old Stones versus Modern Identities, Brill, Leiden 2015, not least, the proposition that modernization and destruction are two sides of the same coin, with museums providing the 'supposed' safeguard. Supposed as it can be suggested that the exhibition of "deracinated orphans" in museums, itself fuels further collection, and, rather than being a safeguard, it seems evident that collections and museum exhibitions and displays themselves function as an incentive to further collecting.
} 
including the number of lines, the size of letters, the particular letter forms, the presence of guidelines, any remains of applied colour and its support, etc.

It seems to have been the Bishop of Agria (Eger), Antonius Verantius's transcription of the Res Gestae Divi Augusti and the copy of it made by Busbecq's servants in Ankara in 1555 which, when circulated and then published ${ }^{2}$ (Fig. 5), underlined to European scholars by the end of the $16^{\text {th }} \mathrm{c}$. the importance of the surviving ancient epigraphic record in Asia Minor. However, the search for ancient Greek and Latin inscriptions in Asia Minor, as elsewhere in this period needs to be understood within the context of the importance given to the precedent provided by Roman models, Republican and Imperial, in the ongoing Europe-wide disputes between Emperor and Papacy, of authority for rule, and in Reformation polity formation and justification, in which the precedents adduced or recorded from antiquity played an important role. Busbecq wrote that the hatred for Desiderius Erasmus (1466-1536) derived from the fact that, "he has sent the world to school with Greece and Rome for its masters." ${ }^{3}$, rather than Christ, the Apostles and the Popes, and, in this, for Europeans the study and collection of Greek and Latin inscriptions played a role in the attempts at resurrecting the nature of the pre-Christian world, an element in the justification of models for rule, Republican and Imperial, in the Renaissances of Europe. Driven by collectors, humanists and antiquarians, the $16^{\text {th }} \mathrm{c}$. saw the beginning of the attempt by Europeans to understand ancient Roman Asia Minor through both the criticism of the surviving often corrupted literary sources and from the growing range of circulated and published collected epigraphic and numismatic material. Ogier Ghiselin de Busbecq-Busbequius (1522-1592) described his antiquarian mission in Asia Minor in the following words: "And why should not you help in this work, Ogier? There are manuscripts yet to be discovered, there are inscriptions yet to be copied, there are coins of which no specimen have been gathered."

Over this period of 400 years, in Turchia, Turquia, the Beylik bilad ar-rūm, in Ottoman Anatol, Natolia, Asia Minor/Asia Mineure, there was the transcription of much ancient epigraphic material by antiquarians from Europe, together with the "gathering," selection and the removal where practicable of important epigraphic documents: inscriptions, coins, medals, carved gemstones, as also ancient manuscripts ${ }^{5}$, together with the selection and removal of antique "marbles," statues and relief sculptures. A variety of methods and means were employed, with the assistance of merchants, envoys, ambassadors and consular officials, largely Venetian, French, Dutch and English (after 1707) British. ${ }^{6}$ In any attempt to place in context the $19^{\text {th }}$ to $21^{\text {st }} \mathrm{c}$. Eu-

\footnotetext{
${ }^{2}$ Joseph Pitton de Tournefort records, "the inscription is to be found in the Monumentum Ancyranum Gronovii and in Gruter. Leunclave had of it, Clusius (Charles de L'Ecluse, the botanist of tulip fame and antiquary), ...And Faustus Verantius, who communicated this piece to Clusius, had it from his uncle from Venetian Croatia, Antonius Verantius (1504-73), Bishop of Agria (Eger) and Ambassador (in 1553-57 and 1567-1587) of Ferdinand II. to the Porte. This Prelate caused it to be transcribed as he passed by Angora. Busbequius took a Copy of it, ...” Tournefort 1741, Vol. 111, 286.

${ }^{3}$ Busbecq 1881, 47.

${ }^{4}$ Busbecq 1881, 47.

${ }^{5}$ For example the merchant and dealer in antiquities, Paul Lucas, returned from his 1705-1707 voyage with 22 manuscripts.

${ }^{6}$ For example the Ambassador Extraordinary and Minister Plenipotentiary of His Britannic Majesty to the Sublime Porte from 1775 to 1793, Sir Robert Ainslie collected Greek and Latin inscriptions and other
} 
ropean interest in the epigraphic record surviving from antiquity in Asia Minor, a study of earlier European antiquarian activity in Asia Minor provides us with a range of valuable precedents, not least in the relationship between envoys from European states in Asia Minor and antiquarian activity ${ }^{7}$ (Table II), that then precipitated into the various European national archaeological institutes established in Constantinople-Istanbul in the second half of the $19^{\text {th }}$ and early $20^{\text {th }}$ centuries. It also provides some reasons why European antiquarian activity in respect to the ancient inscriptions in Asia Minor had been regarded with suspicion by the Ottoman State and by some of its inhabitants for centuries before Lt. Col. W. M. Leake in his 1824 publication suggested two of the reasons for this suspicion, firstly, the inhabitants thought the foreigners were spying out the land for a future invasion, "or (that they were in) a search after treasure amongst the ruins of antiquity." "The latter suspicion was alive two hundred years earlier, as the English Ambassador Sir Thomas Roe related in a letter to the Duke of Buckingham of May 1627, "From Angory, I had a hal(f)-woman, brought 18 dayes by land, upon change of mules, which wants a hand, a nose, a lip; and is so deformed, that shee makes me remember an hospital. Yet the malicious Turkes brought trouble on the buyers, by a false command, accusing them of a great wealth stolen out of the castle; it hath cost mee money to punish them, and that is all I have for my labor." A fuller account not only of the European, but also of the varied Ottoman perspectives, the various views of rulers, alim, clerics ${ }^{10}$, city dwellers, villagers ${ }^{11}$ and nomads, of the members

antiquities which were shipped to England in the frigate 'Pearl' in 1789; as also Lord Elgin in 1799 (see below).

${ }^{7}$ This became part of official recognised expected and regular British consular activity by 1864 when a Foreign Office circular was sent out to all acting consuls, making the search for antiquities part of their official duties (on this see Gunning 2016). Hence, for example Alfred Billiotti, British vice-consul on Rhodes between the 1856 and the 1870's, "who acted as an agent for Charles Newton in acquiring antiquities for the British Museum." http://www.britishmuseum.org/research/search_the_collection_database/ term_details.aspx?bioId=97427 He was an excavator of antiquities at Halicarnassos with Auguste Salzmann, after Consul Charles Newton left the site, and with Auguste Salzmann at Kameiros in 1852-1864, and at Ialysos from 1868 to 1871, where he excavated the first collection of Mycenean jewellery, at Didyma in 1874, and, again excavated on Crete 1885-1897 in his capacity as British Consul. E.g., "Mr Albert Billiotti, the British Pro-Consul at Rhodes, who in conjunction with his brother has been carrying out excavations for some years, has sent me the following eight inscriptions which he has noted from time to time and which, so far as I know, are unpublished." Smith 1883, 136.

${ }^{8}$ Leake 1824, Preface v.

${ }^{9}$ Hervey 1921, 274.

${ }^{10}$ For example, to what extent did Rum-Greek priests facilitate the removal by European antiquarians of the remains of pagan antiquity from Asia Minor, not only, or solely for the money, but also to protect the orthodox believer, in the centuries prior to the formulation of Greek nationalism in the late $18^{\text {th }} \mathrm{c}$. with its ideological relationship with ancient Greece as it was then understood? To what extent did Augustine of Hippo's charge made in his City of God, relating Roman religion to magic and necromancy, serve not just as a call to destroy the Pagan remains, but to remain distant from these remains, or otherwise be associated with the practice of necromancy and other diabolical practices? As also, to what extent were the surviving pagan remains protected from casual pillage by the Rum inhabitants, due to the understood presence of demons recorded in many of the recorded lives of saints, inhabiting the remains of Pagan antiquity. Clive Foss in Byzantine and Ottoman Sardis writes: "Crosses were carved on the temple of Artemis to nullify the power of the demons who, it was believed, dwelt in the material of pagan edifices." 
of the various Ottoman millets in respect to these ancient remains, including 'written stones,' over the course of these four centuries, remains a desideratum.

Table I) An incomplete list of Asia Minor's ancient sites visited by Europeans between 1400 and 1800 where inscriptions were noted and/or transcribed or removed

1400-1500 Kyzikos, Nicea, Pergamon, Kyme, Lampsacus, Troy, Didyma, Kyme, Smyrna, Sardis, Phocaea, Miletus, Ephesus

1500-1600 Nicomedie, Ruines de Troye, Tarsus, Adana, Heraclée-Heraclea, Cogne-IconiumKonya, Achara-Ankara, Nicea

1600-1700 Troy, Lampsacum, Sinope, Ankara, Brussia, Amasia, Pergamo, Assos, Smyrnaİzmir, Ephesus, Magnesia ad Meandrum, Cladie (?), Konya, Eski-Attalie-Side, Satalie-Sattaliya-Antalya, Nice-Nicea-Iznik, Trebisonde, Nicomedia-İzmit, Seliori, Eregli, Sardis, Kyzikos, Eskihisar, Thyatira-Akhisar, Laodicea, Philadelphia, Hierapolis, Panionium, Miletus, Iotan-Didyma, Askem Kalesi, Mylasa-Milas, Manisa (Magnesia ad Sipylum), Bursa, Metropolis, Lampsacus-Lapseki, Clazomene, Angora, Cesarea-Kayseri

1700-1800 Ankara, Sinope, Heraclea, Smyrna-İzmir, Manisa, Eskihisar, Thyatira-Akhisar, Laodicea, Philadelphia, Hierapolis, Sardis, Derrekoy by Sardis, Marmara, Soma, Torbali, Nicomedia, Sigeum-Ilium-Troy, Jeronda-Branchidae-Didyma, Teum, Teos, Tralles, Nissa, Tyria, Aphrodisias, Miletus, Stratonicea-Eskihissar, Vourla, Attourla, Colossae, Iasos, Ephesos, Colophon, Metropolis, Nazilli, Turgutlu, Kuşa-

(Foss 1976, 34), as likewise Pococke records in respect to the Augustus temple at Mylasa, "This building, when Christianity prevailed, was doubtless converted either into a church, or some other public building; for on the stones of the temple I saw several defaced inscriptions, with the cross on them." (Pococke 1745, II, 61). And in 1452, with church union, it was thought by the Orthodox that Hagia Sophia in Constantino-

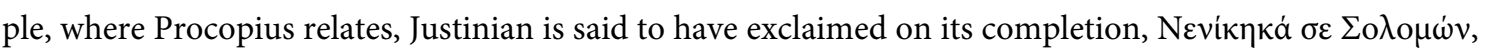
"Solomon, I have outdone thee?", had become the abode of demons, becoming a pagan temple, and so the Orthodox left the Great Church unvisited. Likewise, to what extent were Muslim attitudes towards the remains of antiquity shaped by the literary and popular discourse that had repeatedly, over the course of many centuries, associated ancient sites, hidden treasure, the remains of antiquity, inaccessible ravines, and disease, with the malevolent Jinn-Ifrits and ghouls, thereby protecting ancient remains from human disturbance?

${ }^{11}$ To perhaps better understand this other context within which ancient remains and written stones were understood, by both Christian and Muslim populations, it is worth reading Mahmut Makal's Memleketin Sahipleri (The Masters of the Country) of 1954, which describes from his own experience as a village school teacher, the local jinn, saints and devils dwelling in caves, tombs, sacred wells and trees, those forces so named that played such an important role in the life of the villager over the past millennia, forces that inhabited the mental landscape in a more proximate manner over the past millennia than is often realised today, and who, from Makal's opinion, an opinion formed by the middle of the last century, are the real "Masters of the Country." as is likewise recorded in Yaşar Kemal's Yer demir gök bakır (Iron earth Copper sky) of 1963. See for examples Anderson 2015. In prioritising the importance of the literal text of ancient inscriptions, over the way the written stone was subsequently and differently understood over time by the local inhabitants, our understanding of the more recent past's relationship with these remains may be distorted, while clarifying in places our understanding of the history of antiquity. 
dası, Parium, Perinthos, Seluccia, Cilician Gates, Konya, Eskişehir, Mylasa-Milas, Cnidus, Halicarnassos-Bodrum, Çardak Köy facing Gallipoli, Alexander TroasAssos, Brussa, Cizicus-Cyzique, Nicea-İznik, Telmessos-Makri-Fethiye, Patara, Myra-Andriake, Kekova, Antiphellos-Kaş, Bergamo-Pergamus, Thymbrius, Cymae-Carina-Heraclea, Bithynian Eraclei, Apollonia.

Table I indicates that of the antique sites in Asia Minor, it was largely Troy and the Troad and those cities in Aegean coastal areas and on major trade routes that were visited, where inscriptions were recorded and/or removed. In particular, from the $17^{\text {th }} \mathrm{c}$. onwards, those proximate to Smyrna-Izmir, with its Venetian, French, Dutch and English Consulates. But the majority of Greco-Roman cities-sites in Asia Minor remained unvisited before 1800. The Biblical sites unvisited by antiquarians to 1800 included: Pisidian Antioch, Perge, Lystra, Derbe, and Phaselis; and, amongst those sites known from ancient sources but unvisited by 1800: Aspendos, Xanthus and the Letoon, Side, Termessos, Limyra, Tlos, Pinara-Minare, Rhodiapolis, Caunos, Silenus, Claudiopolis, Ariassos, Apamea, Eumenia, Pessinus, Sagalassos, Cremna, Cibyra, Philomelion, Amorium, Selge, Azanoi, Kelendres, Synnada, Anemorium, etc.

Table II) An incomplete list of the dates of visits of those Europeans to Natolia-Asia Minor, individual or group, who noted, recorded and/or removed ancient Greek and/or Latin inscriptions. The dates of diplomatic envoys and consular officials recorded as involved in these activities are given in bold

1400-1500 Italian city states (Florence, Ancona) 1414-1422 \& 1430; 1412, 1431, 1435, 1444, 1446, 1447, and acquisitions amongst others for Cardinal Domenico Grimani's (1461-1523) collection donated to the city of Venice, in part from Rome, Crete and almost certainly Asia Minor as some of the sculpture, coins and gems came from the Levant.

1500-1600 French 1546-9.

Austrian 1554-55, 1556-62, 1588-9. Bilingual copy of the Res Gestae Divi Augusti, transcribed 1555, published Andreas Schott 1579.

1600-1700 English 1610; 1627-30; 1621-8; 1627-8; 1628-39; 1638, 1670-1678; 1668-71, 1673, 1675-76; 1698-1702. 'Parian Chronicle, purchased in 1624 and taken from Smyrnaİzmir to London, published in Marmora Arundellina, ed. John Selden in 1628.

French 1624, 1633; 1641; 1675-76; 1699-1707.

Holland-Dutch 1630, 1674-81.

1700-1800 Holland-Dutch 1700-1709; 1703, 1705-06, 1716, 1724-59.

French 1701, 1701-1702; 1716; 1737, 1754; 1757-65; 1776; 1784-6, 1786; 1797.

British 1705-18; 1705; 1709-16, Bilingual Prices Edict of Stratonicea copied 1709, 1716; 1718, Sigaean decree of Antiochus Soter of 278 B.C. removed by Amb. Edward Wortley Montague; 1727, 1732, 1737-38; 1738-9; 1739-1740; 1749; 1764-5; 1792; 1795-6; 1799; 1799-1801. Attic-Ionic 'Sigaean Phanodikos Inscription,' c. 550 B.C. first transcribed 1716 by Homero, published by Chishull in 1721, removed by William Wittman and Sir Richard Phillips for the Amb. James Bruce, $7^{\text {th }}$ Earl of Elgin 1799 with firman from the Porte.

Florence, Naples 1779; 1792

Table II shows rapidly increasing antiquarian interest from the start of the $17^{\text {th }} \mathrm{c}$. onwards in the visible surviving ancient Greek and Latin inscriptions, part of the increasing European interest in the remains of antiquity, in a climate of increasing contacts and trade with Ottoman Asia Minor largely through the 
Aegean port of Smyrna-Izmir with the issuance of the Ottoman, so-called capitulations. ${ }^{12}$ There were certainly more removals of epigraphic material from Asia Minor to Venice and Genoa than are presently recorded in the modern literature.

Table III) An incomplete list of antiquarians and those with an interest, scholarly and/or financial in antiquities, who reported on the presence of, transcribed (and at times, collected and removed) ancient inscriptions from Asia Minor ${ }^{13}$.

1400-1500 Ciriaco de Pizzicolli/Cyriacus of Ancona (known to Pope Eugenius IV, to John VIII Paleologus), 1412, 1431, 1435, 1444, 1446, 1447.

1500-1600 Envoy Sieur d'Aramont, with Pierre Gilles and Pierre Belon 1546-49, Petrus Antonius Verantius, Envoy Bishop of Agria (Eger), and Ogier Ghiselin de BusbecqBusbequius 1554-1555, 1556-1562.

1600-1700 George Sandys 1610, Sir Thomas Roe, English Ambassador to the Porte 1621-1628, Thomas Markham, Rev. William Petty 1620's, French Consul in Smyrna, Sanson Napollon 1624, Sir Peter Wyche, English Ambassador to the Porte 1627-1641, Fra. P. Théophile Minuti 1633, Rev. Thomas Greaves 1637-1638, Rev. Edward Pocock, December 1637 to August 1640, Sieur Du Loir 1641, Dr. John Luke, 1664-9 and 1674-83, Dr. Thomas Smith, Levent Company Chaplain 1668-71, Rev. John Covel 1670-1678, Johann Michael Wansleben 1670, Sir Paul Rycaut 1670-1678, Dr. Pickering 1673, Cornelis de Bruijn 1674-81 (in the Levant), Jacques (Jacob or James) Spon of Lyon and George Wheler 1675-76, Rev. T. Smith chaplain to the English factory at Smyrna 1683, Daniel Cosson, Rev. Edmund Chishull chaplain to the English factory at Smyrna 1698-1702, Sieur Aubry De La Motraye 1699, 1707.

1700-1800 Envoy Johannes Aegidius van Egmond van der Nijenburg, United States of Holland representative Smyrna, and Johannes Wilhelmus Heyman, 1700-1709, Joseph Pitton de Tournefort, Marquis de Nointel 1701-1702, Paul Lucas 1705-Feb. 1706, 1715, Rev. John Tisser 1701-1710, Dr. William Sherard 1705-1717, Rev. Samuel Lisle 1705-1716, with Dr. Antonio Picenini, C. Lockwood, J. Lethieullier (1705 Smryna) and William Sherard's consular dragoman S. Homerus, Rev. Chaplain Bernard Mould 1716-24, Rev. Vandervecht and Jos. Clotterboke, M. L'Abbé Francoise Sevin, Anne Claude Philippe de Tubieres, Comte de Caylus. 1716, Amb. Edward Wortley Montague 1718, Rev. Charles Burdett 1724-1751 chaplain to the

${ }^{12}$ Issued to the Genovese 1352, Venetians by 1387, 1403, 1411, 1419, 1430, 1446, 1454; Florentines 1450's, Naples 1498, French 1517, 1569, English 1580, Netherlands 1612, İnalcik 1997, I. 194. These record protection and tax-trade concessions for bearers. They do not record nor grant any permission to remove antiquities.

${ }^{13}$ An extensive list of the names and dates of the Venetian, Genovese, Florentine and, English, French and Dutch merchants and captains of vessels who removed inscriptions from Asia Minor, in addition to the few mentioned here, fn. 50, is certainly a desideratum. It seems probable that some of the inscriptions in the $16^{\text {th }}$ c. collections at Prague Castle and Castle Ambras, came from Asia Minor via Genoa, and, as Krista de Jonge and Koen Ottenheym, remark, "Apart from real or fake antique statuary, the best way for the elite to dress up their residences in the antique manner was actually to import marble artefacts from Genoa, the main hub in the all'antica luxury trade." de Jonge - Ottenheym 2007, 75. For a $12^{\text {th }}$ c. Genovese consignment of coloured antique marble columns from Palestine that sunk in the Gulf of Adalia, Greenhalgh 2009, 386. 
English factory at Smyrna, Captain Thomas Morley/Morly 1732, John Montague Earl of Sandwich (with Brabazon Ponsonby, 2nd Viscount Duncannon and Earl of Besborough, Mr Nelthorpe, Mr Mackye and Swiss painter Jean-Étienne Liotard) 1737-1738, Daniel Alexander de Hochepied Consul General of States of Holland at Smyrna 1724-1759, Arthur Pullinger 1733, 1738-9, M. Jean Otter 1737, Richard Pococke 1739-1740, James Caulfield, Lord Charlemont, Mr. Francis Pierpont Burton, Mr. Scott, Rev. Edward Murphy and artist Richard Dalton 1749, M. Le Roy 1754, M. de Paysonnel and M. Le Beau, 1757-1765, Rev. Dr. Richard Chandler, Mr. Revett and Mr Pars, August 1764-August 1765, Sir Robert Ainslie, Ambassador Extraordinary and Minister Plenipotentiary of His Britannic Majesty to the Sublime Porte from 1775 to 1793, Gabriel Florent Auguste de Choiseul-Gouffier and his party of savants 1776, Abbé Domenico Sestini 1779, J. B. Lechevallier 1784-6, Luigi Mayer 1792, Thomas Hope, Mr Edward Lee (Levent Co. Merchant) 1795, John Bacon Sawrey Morritt and Rev. James Dallaway 1795-6, Guillaume-Antoine Olivier, Prof. Rev. Joseph Dacre Carlyle 1799, Thomas Bruce $7^{\text {th }}$ Earl of Elgin and Kincardine, Ambassador Extraordinary and Minister Plenipotentiary of His Britannic Majesty to the Sublime Porte from 1799-1803.

The term 'epigrapher' appears to have first been used in 1843 in French ${ }^{14}$, in 1851 in English $^{15}$, the word 'epigraphist' in English from 1864 onwards; while, The Saturday Review of Politics, Literature, Science, Art, and Finance, on the $18^{\text {th }}$ of July, 1863, related, "The science of epigraphy seems still, as far as Britain is concerned, to be quite in its infancy." 16 And so, for this period from 1400-1800, antiquarian ${ }^{17}$, from the Latin antiquarius, or, antiquary ${ }^{18}$, seem to be the more appropriate terms ${ }^{19}$, rather than to use the modern scientific term, 'epigrapher,' or the modern

${ }^{14}$ Panciera 2012, 1-10, 2 fn. 4.
${ }^{15}$ s.v. "epigraphy" S.O.D. ${ }^{3} 1969$.
${ }^{16}$ Sandys $1919,1$.
${ }^{17}$ s.v. "antiquarian" S.O.D. ${ }^{3} 1969$, used from 1610 onwards, "1. Of, or connected with the study of antiquities." The former distinction was between the study of 'antiquities', being the study of the physical 'remains', the 'fragments', archaeological remains, objects, inscriptions or isolated documents, as distinct from 'annals,' on the course of history, historical chronicles. From antiquities, Ar. Antiky/antikát.

${ }^{18}$ s.v. "antiquary” S.O.D. ${ }^{3} 1969$, “B. 2. An official custodian or recorder of antiquities (A title bestowed by Henry VIII upon Leland). 3. A professed student, or collector, of antiquities."

${ }^{19}$ The word "antiquary" meaning the study of the ancient, in all its varied aspects, the remains and relics from the past, any form of written text, of customs, architecture, coins and seals, pottery, megaliths and stone circles etc., was first used in English in 1563, the College of Antiquaries was established c. 1585, the Society of Antiquaries of London from 1707, established by Royal Charter in 1751, the Dilettanti Society was founded in 1734; of antiquarians, educated travellers who took an informed interest in, recorded and collected and, at times, published evidence of past civilisations, including ruins, statues, epigraphic material, coins and papyri, and the related recording of views of the ancient site, object or structure, sometimes in plan, elevation and section, work often provided by artists and architects they employed. Francis Bacon (1561-1626) the advancement of learning Bk. II., observed that, "Antiquities are history defaced, or some remnants of history which have casually escaped the shipwreck of time." This was then misquoted (PSRL I, 200-201) and subsequently repeated, to read: “Antiquities may be look'd upon as the 
expression, 'proto-epigrapher, ${ }^{20}$ to describe these people whose education in respect to ancient inscriptions, was often, although not always, simply an ability to read and who at times chose to record ancient Greek and Latin inscriptions. Latin and ancient Greek being an integral part of all European university (and seminary) education from the $16^{\text {th }}$ into the $20^{\text {th }}$ century, as also Hebrew, for those who studied theology, Abbé, Fra. priest, minister, Reverend or chaplain. Those who came to Asia Minor during this period were by profession, merchants, artists, architects, envoys and consuls and wealthy travellers, nobles and gentlemen on tour, some botanising, ${ }^{21}$ the collecting of plants and of making copies of ancient inscriptions being closely related in Asia Minor, as elsewhere, educated, able to read ancient Greek and Latin inscriptions, the majority having an antiquarian interest, rather than it being their sole concern. It was understood as early as the $15^{\text {th }} \mathrm{c}$. that the evidence provided through surviving ancient inscriptions could supplement and at times correct the reading of surviving copies of ancient literary texts, shown by the interest generated in Italian humanist circles by the inscriptions transcribed by Cyriacus of Ancona/Ciriaco de Pizzicolli (1391-1453/55), who himself could not read for years the ancient Greek of the inscriptions he transcribed in the "going backward and forward into Greece, and drawing forth from obscurity the productions of the most enlightened ages of antiquity. Add to all this...the thirst of discovering monuments and remains of a remote antiquity, that animated Ciriacus of Ancona and others to the most laborious researches in Italy, Greece and the East." ${ }^{22}$ In 1670 the German scholar working for the French Minister Colbert, Johann Michael Wansleben, was sent to Asia Minor "with official instructions, which underline the value of epigraphy to the study of the ancients, as the voice, they supplemented where ancient authors were silent." 23

Planks of a Shipwreck, which industrious and wise Men, snatch up and preserve from the deluge of time." Although, rather than 'the planks of a shipwreck,' perhaps 'deracinated orphans' is a more accurate term.

${ }^{20}$ Like the term minted in the $20^{\text {th }}$ c., Proto-archaeology, sometimes employed to describe the period of excavations from 1860-1914 when a scientific methodology was being developed; but a term which is more often employed by archaeologists today to co-opt into the modern discipline, antiquarianism, as 'proto - archaeology,' although it remains the case that the subjects of antiquarian interest over the course of history, in antiquity, as in the Medieval period, down to the present day, concerns a far wider range of approaches and varieties of material than that studied by the modern discipline of archaeology, and therefore the term proto-archaeology cannot be an accurate synonym for the work undertaken by an antiquarian. The word 'archaeologist' employed to mean a person undertaking the scientific study of ancient peoples and past civilisations, is only recorded in English usage from 1824 onwards, with the Royal Archaeological Institute (RAI) established in 1844, distinct from the related, but different research and documenting activities of antiquarians, such as those who dug at Stonehenge in the $17^{\text {th }}$ century and the cities of Pompeii and Herculaneum in the $18^{\text {th }} \mathrm{c}$., when the digging was not conducted by ordinary treasure hunters, it was not conducted by anybody who thought of themselves or described themselves as archaeologists, such work was carried out by antiquaries into the $19^{\text {th }} \mathrm{c}$.

${ }^{21}$ The botanists who also transcribed inscriptions included: Pierre Belon, Ogier Ghiselin de Busbecq, George Wheler, Joseph Pitton de Tournefort, and W. Sherard.

${ }^{22}$ Review of, "Storia Della Letteratura Italiana, etc., An History of Italian Literature. By the Abbot Jerome Tiraboshi, Vol. VI." 541-533, The Monthly Review, Or, Literary Journal, LVI, Art. XIII, 1777, 532.

${ }^{23}$ Greenhalgh 2013, 236, note 20. 
There was however almost no European antiquarian interest in this period in inscriptions in Asia Minor as providing "the voice" in other languages, little even in the Christian inscriptions in Medieval Greek. It was in the second half of the $17^{\text {th }} \mathrm{c}$. that Dr. John Luke, the Chaplain to the Levant Factory at Smyrna (from 1664 to 1669 and from 1674 to 1683) drew attention to, and was a driving force in investigating the historical remains and record of the early church, of the importance of history and of the historical and epigraphic remains in the "reading of the plain meaning" of scripture, and, that, "the supplying of history was to be found in early Christian texts closest to the time, the practices of Graeco-Roman culture, and perhaps most importantly, 'the poor reliques' of once famous and flourishing churches." ${ }^{24}$ Although in respect to inscriptions, the Society of Dilettanti's Instructions to the mission of the Rev. Dr. Richard Chandler, Mr. Revett and Mr Pars were explicit, as to, "copying all the Inscriptions you shall meet with," ${ }^{25}$ it was the case that it was the ancient Greek and Latin inscriptions that were worthy of transcription and publication. The medieval Arabic, Persian, Ottoman and Armenian in situ inscriptions in Asia Minor remained in the main clearly visible, and unremarked upon and unrecorded by European antiquarians in this period, as also sculptures that were not, or were thought not to be, $a$ l'antiqua. ${ }^{26}$ Antiquarian interest in these other inscriptions and their historical and religious content and context, together with the linguistic skills to read them, were largely, although not entirely, ${ }^{27}$ lacking. An exception being an anonymous English traveller in 1667 who described the Satalia-Antalya sea-gate and remarked on the presence on it of an inscription in Arabic: "One of the Gates near the sea, not of the city, but of some outbuildings on the scala (SataliaAntalya mina), presenteth on each side a statue of stone, in mannar not much unlike those at the gate of Southampton ${ }^{28}$, but much less; the right hand statue bearing on his right hand, in fair let-

${ }^{24}$ For the importance of his sermon to the Levant Company board in 1664 on this matter of the remains of Early Christianity, see Cadwallader 2014, 207-9. See also Smith 1678.

${ }^{25}$ Chandler 1776, viii.

${ }^{26}$ The 'newe' figurative stone statues brought at great cost to Ambassador Thomas Roe, possibly Hittite or Neo-Hittite, but more probably New Roman or Medieval Seljuk sculptures and reliefs, were of no significance, not being a l'antiqua. He wrote to the Earl of Arundel from Constantinople on October the $30^{\text {th }} 1625$, "I have in my endeavour bad success, by the ignorance of those that I am forced to employ, who send me heavy stones at great chardge, that prove newe images, wher I seeke old idolls; for such also were the Roman statues of their emperors." (Hervey 1921, 274.) What happened in the $17^{\text {th }} \mathrm{c}$. to these unwanted, "newe images" is today of considerable interest, but further information concerning the fate of these unwanted "newe" statues seems lacking.

${ }^{27}$ Exceptions in the $17^{\text {th }}$ c. include: the Rev. John Covel who learnt Modern Greek, as also Dr John Luke, Levant Co. chaplain 1664-9 and 1674-83 and then Prof. of Arabic, and Hebrew; Dr. Thomas Smith, Chaplain to Sir Daniel Hervey from 1668 to 1671 the Orientalist, Rev. Edward Pocock, and the Rev. Edmund Chishull who transcribed some medieval Greek inscriptions in Smyrna and Prusia-Bursa, and, in the $18^{\text {th }}$ c., Joseph Pitton de Tournefort, and the Abbé Domenico Sestini, who remarkably transcribed an Ottoman inscription of Sultan Beyazit I. In Aleppo, the Levant Co. Consul 1745-1755, Mr. Pollard employed a Turk to transcribe and another to translate an Arabic inscription that had over the course of more than 840 years been moved from the citadel to the Grand mosque and then to the tomb of the Prophet Zachariah, Drummond 1754, 237.

${ }^{28}$ The medieval Bargate of Southampton (a toll gate) with carved single figure reliefs on either side of the entrance, of 1175 with alterations of c. 1290, which remains in situ today. 
ters insculpted lillahi (Deus) ${ }^{29}$. When I find any images remaining among the Turks, I think it not idle to note them, especially with any sign on them that they are accepted, because known to be generally abhorred by them, more than fire or plague." ${ }^{30}$

The collection and removal of inscriptions from Ottoman Asia Minor: "these may be fetched at charge and secretly; but if we ask leave, it cannot be obtained."

The removal of antiquities, including inscriptions, from Asia Minor seems to have neither a known beginning, preceding the removal of a bronze moving statue automata of Apollo from Didyma to Susa by the Persians in 494 B.C., nor has it any foreseeable end ${ }^{31}$. It is, like it or not, a continuum, an on-going process, spoils, relics, loot, to the powerful ruler, noble collector, director and agents, usually literate at the selection, if not at local collection level, the dealers and the destination, most often to Europe, to the shrine, the palazzo, the cathedral treasury, the mansion and country house, the gallery which is "an essential part of a magnificent residence and appropriate to a museum of natural and artificial curiosities,"32 and, latterly, via the dealer and international auction house, to the modern public museum or private collection. After all, there is little that separates the reasons for, the contents of, and the pilgrimage to, a well-stocked ancient temple treasury, the medieval cathedral treasury, the Popes', Emperor's and princes' treasuries and wunderkammern of artificalia and naturalia, the humanists and antiquarian's collections, and modern national and private museums - they are collections of relics, of antiquities, of evidence of wonders, natural and otherwise, of a variety of talisman, being divided over time only by the surrounding discourse and terminology, by the degree of openness of access to these objects and in the forms of presentation employed for these potent symbols - the isolation through removal from its context and objectivisation through possession, the display of cult, - relics, collectively expressing through their subsequent assemblage - religious, individual, corporate, local, national or international power through the display of their possession.

As earlier, from the $15^{\text {th }} \mathrm{c}$. onwards ancient Greek and Roman antiquities, including inscriptions, coins and medals providing evidence of toponyms, cult etc., carved reliefs and statues were removed in some quantity from Asia Minor, largely from coastal sites, to Europe, in larger quantities from the start of the $17^{\text {th }} \mathrm{c}$. onwards, through the activities of merchants, diplomatic envoys, consuls, and networks of travelling antiquarians/factors-agents. These objects were removed whenever possible through purchase and bribes and smuggled abroad without obtaining Ottoman official permission, as it was well known at the time that official permission would not be granted.

${ }^{29}$ The upper part of this reworked relief is today displayed in the Antalya Archaeological Museum, Inv. No. 156. From the letter sizes and forms, the Arabic inscription dates from the Seljuk period and were added when this relief was re-used in the $13^{\text {th }} \mathrm{c}$., prior to its subsequent re-use in the Lusignan sea-gate, constructed between 1361 and 1373. The sea gate seems to have been demolished in the $19^{\text {th }} \mathrm{c}$. See on this relief, Duggan 2012, 56-61.

${ }^{30}$ B. M. Harl. Mss. 1721 anon. Anon 1800, 187-188. Possibly written by the Levant Co. chaplain, Dr. John Luke, or perhaps the Smyrna Levant Co. Consul Richard Baker, 1660, superseded in 1661, and said to have died in 1661 in Settalia-Antalya, the date 1661 of the manuscript, may have been misread as 1667.

${ }^{31}$ For the recent illegal removal from Lycia to Europe of the inscription in bronze of the RomanLycian Treaty of 46 B.C. and its subsequent publication, see Duggan 2015, 59-70.

${ }^{32}$ Elmes 1824, s.v. "Gallery". 
The English Ambassador to the Porte from 1621-1628, Sir Thomas Roe, himself collected ancient manuscripts and ancient coins and he translated from Latin into English Petrus Gyllius's Topographia Constantinopoleos et de illius antiquitatibus libri $I V$, in $1628^{33}$, his manuscript was published a century later in 1729 by John Ball, who was not the translator as has been rather frequently stated over the past 300 years $^{34}$, but who added the explanatory index to Sir Thomas Roe's translation. Ambassador Roe secured berats from the Porte for Mr John Markham, "sent out to collect antiquities" ${ }^{35}$ for the Earl of Arundel, and then for the Rev. William Petty ${ }^{36}$ to look for and export antiquities ${ }^{37}$ for the Earl. William Petty was indefatigable in his search for antiquities in Asia Minor from 1624, at Pergamo, Smyrna-İzmir, Magnesia, Troy ${ }^{38}$ and elsewhere in Aegean coastal areas and obtained "22 Greek Mss., and raked together 200 pieces." 39 He had secured from Asia Minor and the Aegean Islands for the Earl by 1627, "37 statues, 128 busts, 250 inscriptions, together with a large number of altars, sarcophagi, fragments of sculpture, and an invaluable collection of gems. ${ }^{" 10}$ However, the berat or fiscal ordinance that the English ambassa-

${ }^{33}$ Ball 1729, 317, "In the Beginning of this MS upon a large Folio Page, are inscribed the following Words, in the Benefactor's own Hand. "Sir John (Sic.) Roe, Bart. Ambassador from His Majesty of Great Britain to the Grand Seignior, as a perpetual Testimony of his Gratitude to the University, (Oxon) gave this Book, which he met with in his Travels, to the Publick Library, 1628." It seems John Ball misread a J for a letter T and so misnamed the translator as Sir John Roe, the friend of Shakespeare, Jonson, and Donne, who was in fact the cousin of the Ambassador to the Grand Seignior, Sir Thomas Roe. There was no Ambassador to the Grand Seignior named Sir John Roe and, further Sir John Roe was born the $5^{\text {th }}$ of May 1581 and died a Captain in Ireland in 1608, 20 years before the manuscript was presented to the university by Sir Thomas Roe; see: http://spenserians.cath.vt.edu/BiographyRecord.php?action=GET\&bioid=33075.

${ }^{34}$ Modern instances include: E. Thompson, Possession: The Curious History of Private Collectors from Antiquity to the Present, Yale University Press, 2016, "Pierre Gilles, The Antiquities of Constantinople, trans. John Ball (1729; 2nd ed., New York: Italica, 1988)"; J. Speake, Literature of Travel and Exploration: An Encyclopedia, Routledge, 2014, 626, "Gilles, Pierre [Petrus Gyllius], De topographia Constantinopoleos, et de illius Antiquitatibus libri quatuor, 2 vols., edited by A. Gilles, 1562; translated and published by John Ball as The Antiquities of Constantinople"; R. Stoneman, Land of Lost Gods: The Search for Classical Greece, Tauris Parke Paperbacks, 2011, 305, "Pierre Gilles, The Antiquities of Constantinople tr John Ball, 1729, from the original Lyon edition of 1562"; C. McEvedy, Cities of the Classical World: An Atlas and Gazetteer of 120 centres of Ancient Civilisation, Penguin, 2011, "There is a translation of sorts appended to John Ball's 1729 version of Pierre Gilles..."; L. James, A Companion to Byzantium, John Wiley \& Sons, 2010, 380, "Pierre Gilles: Gilles, P. 1988. The antiquities of Constantinople, based on the translation by John Ball 1729.”; H. C. Evans, Byzantium: Faith and Power (1261-1557), 2004, 618, "Pierre Gilles. The Antiquities of Constantinople (1729). Translated by John Ball.", etc. etc.

${ }^{35}$ Hervey 1921, 266, etc.

${ }^{36}$ Hervey 1921, 265-266. Described by John Selden in Marmora Arundellina, Oxford 1628, "Guilielmi Pettaei, in orientem ad illud negotii non sine honesto commeatu missus, insigni id genus mercium frequentia (ut statuas, figuras insculptas, numismata, \& quae sunt ejusmodi caetera selectissima praetermittam) gestionis cui praeficitur sumptus effusisime repensat." Selden 1726, 1439.

${ }^{37}$ Hervey 1921, 265-266.

${ }^{38}$ Roe 1740, 495.

${ }^{39}$ Rees 1819, s.v. "William Pettie-William Petty," the presumed translator from Greek into English of the manuscript entitled The Commentary of George Aeropolita, dated, $6^{\text {th }}$ February 1644.

${ }^{40}$ Metropolitana 1845, 800; Elmes 1824, s.v. “Arundelian Marbles.” 
dor secured for these agents did not record any official permission to "rake together," to collect and to remove any antiquities, antiquities such as inscriptions and manuscripts of ancient texts and such are unmentioned in these official documents ${ }^{41}$. This is evident in the Ottoman arrest in 1624 of the French Consul in Smyrna, Sanson Napollon ${ }^{42}$, at the same time also factor-agent for the antiquarian Nicolas-Claude Fabri de Peiresc (1580-1637) ${ }^{43}$. He was arrested at Smyrna with a collection of antiquities including inscriptions, for which he had paid 50 crowns, ${ }^{44}$ bought from the Ottoman Cyclades and these were confiscated, clearly indicating the immunity provided by Ottoman berat, or even in being the Consul of a great European power, did not, in fact, extend to cover the activities of European diplomats, consuls and others collecting antiquities in Ottoman territory, and this was a fact that was certainly well understood at that time by those who undertook the collection and export of antiquities from Ottoman territory.

Sir Thomas Roe himself dispatched many servants to many quarters of the Ottoman State, Greece, the Islands and Asia Minor in the search for 'marbles' for the Duke of Buckingham, but they were repeatedly beaten to the best pieces by the Earl of Arundel's man, the Rev. William Petty. Thomas Roe was assisted in his search by the Scio born titular Roman Catholic Bishop of Smirna, Fra. Pietro de Marchi (d.1645), and Thomas wrote to Sir Isaac Wake, English Agent in Turin in $1626^{45}$, to try and secure for the titular Bishop the vacant post of Bishop of Scio, through soliciting the aid of Bandini, the Cardinal of Savoy (1596-1629). He wrote to Sir Isaac: "he will and does assist me for marbles for the duke (of Buckingham), having been bishop long of St. Errinna in the Arches, and in all those islands of great authority" ${ }^{\prime 4}$. Sir Thomas Roe wrote to the Duke of Buckingham in May 1627, "I am this day sending a dragoman, and janizarie, with an Italian to Brussia, the antient metropolis of Bythinia, where, I am informed, are many marbles; and I attend a return from Sinope on the Black Sea, in Amasia, Thus your grace will approve my diligence, and accept the success according to your own benignity. The difficulty of carriage, and engines, and expense, is great, and the danger among these more remote habitations greater, some stones weighing about 20 hundred (weight), and brought by hand to the water; yet your grace shall have no cause to repent the charge; for I hope to make you a noble collection. If you please to continue this search, there will be found daily many rare matters, the poor people being set to work, in hope of gain, and all these parts full of the enquiry made by me and Mr Petty; all above

${ }^{41}$ See for example that issued at Constantinople to the French Ambassador in 1604, of 42 articles, not one of which mentions antiquities in any manner whatsoever, but is concerned with trade, customs and taxes, translated, De La Motraye 1723, 387-393; as likewise there is no mention of antiquities in that issued at Constantinople in 1626, translated Roe 1740, 603-605.

${ }^{42}$ The French superintendent of finance's special envoy to the Levant. His nephew, Sanson le Page, Premier Héraut d'Armes de France, au titre de Bourgogne, Secretaire Interprete de sa Majesté, also collected inscriptions for de Peiresc.

${ }^{43}$ Also spelt Peirese, Peiresk; Nichols 1812, Vol. II, 2.

${ }^{44}$ Knight 1866, 596; Gassendus 1657, 33-34.

${ }^{45}$ Sir Issac Wake, the first to plant pines and firs in England in the grounds of his house at Hampstead, had supplied chests of glass from Venice to the Duchess of Buckingham and others in 1625, CSP 1858, 211.

${ }^{46}$ Roe 1740, 513. In 1621 Pope Gregorio XV had nominated Pietro de Marchi apostolic visitor, vescovo di Santorino, the successor to s. Policarp. 
ground being gone to Venice ${ }^{47}$ we must trust, like miners, to chance; but I find, that the old Christians, to prevent the envy of the Turkes, did in all Greece, and the islands, bury their antiquities, which time and diligence will discover." ${ }^{48}$

Clearly recording the clandestine nature of this activity, Ambassador Roe wrote to the Earl of Arundel from Constantinople May 1624, "I may also light of some pieces of marble by stealth;" He had earlier recorded in a letter to the Duke of Buckingham in January 1623, "I know as well how to send them," meaning he had established a reliable method of smuggling, "Whatsoever I can collect, having now your graces command, added to mine own desire, shall not go of the way to Venice: I know as well how to send them, and have as much affection to serve your grace as any." ${ }^{50}$ Thomas Roe's successor as English Ambassador from 1627-1641, Sir Peter Wyche, another London merchant, was also energetic in this clandestine quest for antiquities, "raking together" for King Charles I., who related in his letter from Constantinople to Edymion Porter of

${ }^{47}$ D. G. Wright (2004) in her review of Bodnar and Foss 2003, remarks, "Cyriac's references support the impression one gets from seeing the remarkable but inadequately known antiquities in the Correr Museum in Venice: lovely small pieces chosen for quality, easily carried by one person in a leather bag or small travelling chest,". But it would seem from ambassador Roe's repeated remarks concerning the role of Venice in the removal of antiquities from Asia Minor, that many larger works of antiquity were removed by the Venetians in the $16^{\text {th }}$ and into the $17^{\text {th }} \mathrm{c}$., than was the case in the $14^{\text {th }}$ and $15^{\text {th }} \mathrm{c}$., Venice being a major centre of antiquities collecting, as with the $15^{\text {th }} \mathrm{c}$. collections of Cardinal Ludovico Tervisan, friend of Ciriaco of Ancona, of Cardinal Pietro Barbo (later Pope Paul II), of the Grimani, as well as Venetian merchants trafficking and dealing in antiquities from the East and in copies/fakes of them, in Italy and into Northern Europe collections. See also Greenhalgh 1989, 240. It seems to have been a Venetian practice in Turkey and elsewhere, that began before the sack of Constantinople in 1204 with its array of looted antiquities brought to Venice, later for example a group of Greek mid- $5^{\text {th }}-$ mid- $4^{\text {th }}$ c. B.C. temple statues found their way from Asia Minor, or the islands, to Greece and the Grimani collection in the $16^{\text {th }}$ c. (JHS 1918, Gardner, 4), and which continued into the $18^{\text {th }} \mathrm{c}$. (noted below) and is an issue which raises serious questions concerning the so-called spread of the cult of antiquity from Florence and Rome to Venice, rather than the reverse being perhaps rather more to the point, at least in terms of the influence of collections of ancient objects including inscriptions.

${ }^{48}$ Roe 1740, 647.

${ }^{49}$ Roe 1740, 154.

${ }^{50}$ Roe 1740, 343-344. He knew as well as the Venetians how to smuggle antiquities. It was using the master of certain trade vessels to transport smuggled antiquities, such as Captain Antony Wood of the Rainbow, in the employ of the Levant Company, the company of merchants which also paid the costs of maintaining the English ambassador to the Porte, himself a merchant of the same company. Rev. Thomas Greaves wrote to Edward Pocock in Constantinople to take, "particular care some marble stones, having inscriptions, which were to be sent by the general ships into England;" (Twells 1740, 13). Like the Venetian merchants, the Turkey Merchants of the Levant Company removed inscriptions, some were presented to Cambridge University (Dobree - Scholefield 1835, 92, No. VII, was presented by J. Hawkins, who had received it from Mr Edward Lee, a (Levant Co.) Turkey Merchant, it was apparently on Tenos in 1795 and was first transcribed in the $15^{\text {th }} \mathrm{c}$. by Cyriacus). Another Greek inscription, in honour of Crato, the musician of Pergamus, erected in the reign of Eumenes, King of Pergamum, 150 B.C., was brought from the village of Segucque-Segyceque-Teos, between Smyrna and Ephesus, by the Levant Company Captain, Thomas Morley in 1732, and brought to London (Dibdin 1810, 49). In the Levant Co. library in Aleppo there were ancient Greek inscriptions Drummond 1754, 237. 
January 1629-30, of the dispatch from Smirna-İzmir on the ship Rainbow, of "19 statues small and great, some of them I hear are rare pieces, and if they prove so, I shall think my labour well disposed. You will be pleased to give an account hereof unto his majesty, and how these be all I have been able to encompass since my arrival in these parts, and I beseech you let me know how acceptable they be, and whether I shall go on in that service still." ${ }^{51}$ Cornelis de Bruijn, who removed from Asia Minor Greek and Latin inscriptions, at Ephesus in November 1678 recorded, "We found there many marble statutes buried in the ground. However, due to the negligence the feet of some of them were outside. I wanted to unearth one of them during the night and to carry it to Smyrna on a carriage. But, I couldn't find anyone to help me even in return for money because they were afraid of our being watched." ${ }^{52}$ A passage indicating that the local population was aware that this proposed activity was illegal, berat or no berat, and, that attention was being paid by the Ottoman state to prevent the removal of antiquities. Such clandestine removal by Europeans was, as is noted above, common practice. At Gallipoli in 1699 Sieur Aubry De La Motraye was struck by the fact that important inscriptions that had already been published by Europeans, first in 1678 and again in 1682, were still in place, they had not already in the intervening two decades been removed. He, "wondered that the Franks had not carried away the stones, whereon were the Inscriptions published by Mr. Spon and Mr Wheeler; one of which ascribes to the Statue of Julia, erected at the Expense of Dyonisus Apollonoteimus, all the Epithets usually given to Ceres; for it lies in a Turk's Garden, who asked me if I would buy it, and sold me some few Paras. I would suppose the Owners of the others, whose Taste does not lie that way, wou'd part as willingly with them for a small matter." 53

Sir Thomas Roe was explicit as to the illegal nature of this activity in his 1624 letter to the Earl of Arundel, concerning the fact that there was no official Ottoman permission for this activity. He wrote:

"On (the) Asia side, about Troy, Zizicum, and all the way to Aleppo, are innumerable pillars, statues, and tombstones of marble, with inscriptions in Greek; these may be fetched at charge and secretly; but if we ask leave, it cannot be obtained; therefore Mr. Markham will use discretion, rather than power, and so the Turks will bring. "다 It seems evident therefore that, although there was no written Ottoman antiquities law published until 1869 which forbade the exportation of antiquities, Ottoman law, as recognised in the $17^{\text {th }} \mathrm{c}$. by the English ambassador, firmly objected to the removal of antiquities from Ottoman territory, ${ }^{55}$ hence, "tombstones of marble, with in-

\footnotetext{
${ }^{51}$ Sainsbury 1859, 353.

52 de Bruijn 1700, 33. "Nous y découvrimes encore plusiers statues de marbre ensevelics en terre, mais avec rant de negligence que les pieds de quelques uncs sortoient dehors. J'eusse bien voulu en déterrer quelqu'une pendant la nuit, \& la porter à Smyrne en vacherre, mais je ne pus trouver personne qui m'aidér mème pour l'argent, par ce qu'ils craignoient qu'on ne nous epiâr." http://gallica.bnf.fr/ark:/12148/bpt6k 85330k/f71.image.

${ }^{53}$ De La Motraye 1723, 303.

${ }^{54}$ Roe 1740, 154. "Discretion" meaning in this context, gold. This was stated explicitly by the Rev. Dr. Richard Chandler in his 1776 publication, "By a proper application of all-prevailing gold," see below.

55 "Before 1869 the legal status of antiquities was regulated only by Islamic jurisprudence. The first such decree specifically regulating antiquities was adopted on February 13, 1869. This decree required permission, when requested, to search for antiquities. It allowed free trade in antiquities within the Ottoman territory
} 
scriptions in Greek; these may be fetched at charge and secretly; but if we ask leave, it cannot be obtained." Consequently, "The premise of Ottoman indifference served as justification for the removal of objects, even entire monuments, from Ottoman territory to western and central European collections", ${ }^{56}$ was, in fact, simply a useful dishonesty, an unfounded but widely articulated and published self-serving premise that served as justification for the removal of antiquities from Asia Minor and elsewhere in Ottoman territory, addressed to a European audience. In the $17^{\text {th }} \mathrm{c}$. as translated by Ambassador Roe, "Gilles laments the state of affairs, blaming both the Muslim Ottomans for their uncaring destruction of the ancient city and the "profound ignorance" of their Greek Christian subjects for their indifference to their vanishing antiquities. ${ }^{\prime 57}$ And this attitude was echoed more widely in the $18^{\text {th }} \mathrm{c}$. in Europe, not least through Edward Gibbon in Vol. VIII, of his 'Decline and Fall of the Roman Empire,' of 1788, “The Athenians walk with supine indifference among the glorious ruins of antiquity; and such is the debasement of their character, that they are incapable of admiring the genius of their predecessors. ${ }^{35}$, until the connection between nationalism and the remains of antiquity became ideology $y^{59}$. Hence the ongoing search, removal, collection, and illegal export of antiquities, including inscriptions, by Europeans was reinforced and justified through the widespread publication of this self-serving misinformation, an attitude still repeated today in respect to the $18^{\text {th }} c^{6}{ }^{60}$ and which is noted in 2015 by Benjamin Anderson in an ethno-archaeological context, concerning the reaction of local populations in Ottoman territory to the removal by Europeans of antiquities. ${ }^{61}$ The Rev. Dr. Richard Chandler wrote in 1776, towards the end of these 400 years, concerning his suggested prize for his planned clandestine removal of an inscription from the Troad: "By a proper application of all-prevailing gold, it is believed they might gain the permission or connivance of the papas and persons concerned. It should be done with secrecy." ${ }^{.2} \mathrm{He}$ also noted of the three inscribed pedestals he saw at

but prohibited exportation. The finder of antiquities on his land was considered the owner. So, the 1869 decree allowed private ownership over antiquities found within the Ottoman territory - within limits." Özel 2010, 178. It is noteworthy that this legislation reiterates that known to Ambassador Roe 250 years earlier, that the exportation of antiquities from Ottoman territory was prohibited.

${ }^{56}$ Anderson 2015, 450.

${ }^{57}$ Matthews 2015, 82.

${ }^{58}$ Gibbon 1788, Ch. LXII, last line. Likewise Ch. LXIV, "The captivity or ruins of the Seven Churches of Asia was consummated; and the barbarous lords of Ionia and Lydia (meaning the Ottomans) still trample on the monuments of classic and Christian antiquity."

59 "German institutions of higher learning in the early nineteenth century, from the Gymnasium to the university, posited ancient Greek language, aesthetics, philosophy, and mythology as the pinnacle of human achievement and as a model for the future. By consequence, the advisers at Otto's court felt themselves in touch with Greek antiquity and predestined to reimport classical ways to the Greeks who had supposedly lost the link to their roots under Byzantine and Ottoman rule." Langbehn - Salama 2011, 127-128.

${ }^{60}$ See for example, Rosenstein 2009, 94, "Since Ottoman rulers were generally indifferent to antiquities of any kind, the conditions for the future purchase of such antiquities as the Elgin Marbles from the Parthenon were established by good precedent."

${ }^{61}$ Anderson 2015.

${ }^{62}$ Chandler 1776, 38-39. It seems a similar attitude to that recorded in Oct. 1881 in his journal by Archaeologist Francis H. Bacon at Assos, "Our plans for the future here at Assos change with every moon. At present are at a standstill for lack of money! There is, however, plenty to do at drawing and measuring. There still remains the disagreeable task of getting the sculptures out of the country and I truly wish that 
Alexander Troas in 1764, that "A Venetian officer afterwards informed us, that he had removed one of them on board his ship, while they lay at anchor near Tenedos, waiting for the Bailow, whose time of residence at Constantinople was expired."63

The John Hopkins University Circular of 1884 carried note of the Lectures on Classical Archaeology, the first of which was given by Dr. Charles Waldstein, Director of the Fitzwilliam Museum, Cambridge, and it related: "Yet the wealth and interest of classic lands two hundred years ago may be judged from the fact that one explorer in the Archipelago returned to Europe with originals and copies of more than two thousand inscriptions ${ }^{64}$. Cyriacus, Spon, even Stuart and Revett, saw and described monuments of antiquity which have now entirely disappeared... The weathering of time, and above all the vandalism of man, steadily continue to deprive us of the material remnants of former civilizations. The rapidity of this destruction must be inconceivable to those not acquainted with the recent history of classic monuments from personal experience." ${ }^{\prime 5}$ Yet, more than 250 years earlier Sir Thomas Roe wrote from Constantinople to the Duke of Buckingham in May 1627 concerning the European antiquarian quest for antiquities in Asia Minor, "If you please to continue this search, there will be found daily many rare matters, the poor people being set to work, in hope of gain, and all these parts full of the enquiry made by me and Mr Petty; all above ground being gone to Venice, we must trust, like miners, to chance; but I find, that the old Christians, to prevent the envy of the Turkes, did in all Greece, and the islands, bury their antiquities, which time and diligence will discover." (emphasis added). ${ }^{66}$ A statement he repeated in a letter to the Duke of April 1628, "Our search hath made many poor men industrious to rip up old ruins." (emphasis added ${ }^{67}$. In consequence, ironically and most unfortunately it can be suggested that it was the longstanding European interest in, search for, and acquisition of antiquities, the sculptural and epigraphic remains of antiquity in Asia Minor, by Venetians, English,

some others than ourselves could take charge of it. ... We can only do our best! You have the photographs and drawings of the sculptures and you can judge yourselves what you can afford to pay for them [in baksheesh to get them out of the country]!” The Assos Journals of Francis H. Bacon - Archaeology Magazine Archive, Dec. $1^{\text {st }}, 2006$.

${ }^{63}$ Chandler 1776, 28. This removal related to Chandler by a Venetian officer, may have led to Chandler's suggestion later made in a footnote concerning the removal of the Boustrophedon inscription at Giaurkoi-Sigéum inscribed on a pilaster from the former temple, "It is to be wished that a Premium (Prize) were offered, and the undertaking recommended to commanders of ships in the Levant trade. They have commonly interpreters to negotiate for them, with men, leavers, ropes, and other requisites, besides instruments or tools, by which the stone might be broken, if necessary. By a proper application of all-prevailing gold, it is believed they might gain the permission or connivance of the papas and persons concerned. It should be done with secrecy. The experiment is easily made, when they are at Tendos, or wind-bound at the mouth of the Hellespont."

${ }^{64} \mathrm{I}$ have been unable to find record of any $17^{\text {th }} \mathrm{c}$. antiquarian who returned with 2,000 originals and copies of inscriptions, and it's probably a misdated reference to Cyriacus in the $15^{\text {th }} \mathrm{c}$. There are a total of 300-400 transcriptions of inscriptions from Asia Minor in, Sherard Mss. B. M. Harlian No. 7509, which seems to represent the larger quantity collected by an individual.

${ }^{65}$ John Hopkins University Circular, 1880-1884, 1884, 132; a point repeatedly made in Greenhalgh 2013.

${ }^{66}$ Roe $1740,647$.

${ }^{67}$ Roe $1740,808$. 
French and Dutch ${ }^{68}$, in exchange for gold, it was the increasing European demand from collectors in the period from the end of the $16^{\text {th }}$ century onwards, that generated the supply, the hunt, which had, "made many poor men industrious to rip up old ruins," and it is the fact that, "the poor people being set to work, in hope of gain," was, and it remains today, a factor of major importance in the destruction of ancient sites in Asia Minor, of the remains of antiquity within their cultural context, producing the countless orphans of no secure provenance that are displayed in museums and private collections worldwide. As the Earl of Arundel wrote to Sir Thomas Roe from Whit(e)hall, May 10, 1625 , "I knowe eyther for some crownes to ye Bashawe (Pasha), they may be had, or els stolen for money by ye Turkes, they caring not for them," ${ }^{69}$. Travellers themselves at times themselves damaged remains in their search for antiquities ${ }^{70}$ and, antiquarian demand also led to the profitable business of counterfeiting, most notably the production of fakes of medals and coins, ${ }^{71}$ adding further confusion to the historical record. It can further be suggested that it was, in part, the European financial incentive, provided by European collectors via their agents, which undermined the established cultural and religious taboo's that had, to a considerable extent, previously protected the remains of antiquity in Asia Minor, this, combined with the mistaken assumption that these ancient remains held no meaning for the present inhabitants.

Until the end of the $18^{\text {th }} \mathrm{c}$. there seems to have been no explicit official permission granted by any Ottoman Sultan through the issuance of a berat, or a firman, which specifically granted permission to remove any type of antiquity, inscriptions, "marbles", ancient coins etc. from Asia Minor $^{72}$ or elsewhere in Ottoman territory. At the end of this period there was the issuance of firmans, in a most particular set of circumstances, the aftermath of the Battle of the Nile (Aboukir) of the $1^{\text {st }}$ of August 1798 and the ending of the French occupation of Ottoman Egypt in 1801, implied at the head of at least one document, "That in order to shew their particular respect for the Ambassador of Great Britain, they gave him and his artists the most extensive permission..." given by the Porte to the British Amb., James Bruce, Earl of Elgin and Kincardine, that

${ }^{68}$ In 1639 it was stated: "Reijnst, an inquisitive man in Amsterdam, has received many antiquities, works of art and beauties from Venice, collected in Turkey, Greece and Italy: statues, tombs, paintings, medals..." Halbertsma 2003, 8.

${ }^{69}$ Sainsbury 1859, 284.

70 "and travellers have enticed soldiers to bring down (shoot down from the metopes on the Parthenon in Athens) heads, legs etc. which were injured, and sometimes destroyed by the fall!" Galignani 1822, fn. 93.

${ }^{71}$ Such as that of "brass, and very ancient, of a queen of Serbia, with hieroglyphicks now unknown" Roe 1740, 16. R. P. Dom Bernard de Montfaucon, remarked, "Pour ce qui est des médailles, on y en pourroit trouver une grande quantité \& de sort curieuses; mais il faut ètre conmnoisseur en ce genre, ou nes'en pas meler. Les Juifs en fabriquent beucoup de fausses qu'ils vendent aux Européens. Il faut d'ailleurs savoir distinguer les rares d'avec les communes, autrement on court risque de faire de la dépense inutilement." Montfaucon 1761, 153-154.

${ }^{72}$ As noted above: see for example, that issued at Constantinople to the French Ambassador in 1604, of 42 articles, not one of which mentions antiquities in any manner whatsoever, but is concerned with trade, customs and taxes, translated, De La Motraye 1723, 387-393; as likewise no mention in that issued at Constantinople in 1626, translated Roe 1740, 603-605. 
explicitly permitted the removal of inscriptions, to "take away any pieces of stones, with figures or inscriptions, which might be interesting to him." ${ }^{\text {t3 }}$

The varied functions of visible ancient inscriptions for the Ottoman state and its inhabitants, distinct from European antiquarian interest

Although the suggestion was made repeatedly by Europeans in the past that the "Turkes, they caring not for them (the ancient remains), ${ }^{74}$ and on into the $21^{\text {st }}$ century, that the Seljuk, Beylik and Ottoman states did not give importance to, and value the ancient remains, such as ancient statues, reliefs and inscriptions, such allegations, as is noted above, were self-serving, as such was not, in fact, the whole story by any means. The reason why Ottoman permission was not forthcoming for the export of antiquities as recorded by Ambassador Roe in the $17^{\text {th }} \mathrm{c}$. and by Richard Chandler in the $18^{\text {th }} \mathrm{c}$. was because these ancient remains, inscriptions (as also ancient sculptures and reliefs) were at times in Asia Minor, as elsewhere in Ottoman territory ${ }^{75}$, understood to carry meaning of considerable relevance and importance to the subsequent inhabitants and to the rulers of different faiths, Christian and Muslim.

Aspects of Late Antique-New Roman attitudes towards the remains of pagan antiquity in Asia Minor are recorded, for example in five chapters of the $7^{\text {th }}$ c. Life of St. Theodore of Sykeon (d. 613), monk and bishop of Anastasiopolis in Galatia. It was understood at that time that with the digging up of mounds or of ancient sites to find building stone, ${ }^{76}$ and implicitly, or explicitly, treasure hunting in the ruins and disturbing the pagan remains, led to the release of demons. "He (Theodore of Sykeon) also sent a letter to Euphrantas, the governor, and stopped him from proceeding against them (the villagers) by satisfying him that the digging in the hillock was not done for the sake of treasure but at the instigation of Satan." improve the adjoining property which belonged to him or in order to carry off some treasure I cannot say." 78 And, "Another time a similar thing happened in the same village. For a marble sarcophagus stood at a certain spot on their boundary and it contained the skeletons of some Greeks (i.e. pagans) of ancient times which were guarded by demons; by the latter's suggestion the follow-

\footnotetext{
${ }^{73}$ Walsh 1825, 48-49. Or, “...or in excavating when they find it necessary the foundations in search of inscriptions among the rubbish;...nor hinder them from taking away any pieces of stone with inscriptions and figures..." Translation of the Italian copy of this firman by William St. Clair, St. Clair 1967, 90. The firman issued in 1799 to William Wittman and Sir Richard Phillips who removed the Sigaeum Phanodikos inscription was issued in this climate and may have been equally explicit in respect to the removal of this inscription and the relief, as "To accomplish this, a firman was procured from the Captain Pacha, who also furnished a chaous to be the bearer of it." Wittman - Phillips 1803, 66-67. It was seen in situ in 1799 by Prof. Rev. Joseph Dacres Carlyle (1758-1804), scholarly advisor to Lord Elgin's party prior to its removal.

${ }^{74}$ Sainsbury 1859, 284.

${ }^{75}$ David Frankfurter notes in respect to Egypt, "For example, spolia-remnants of pre-Christian iconography-were often recycled as potent apotropaia for the supernatural protection of buildings." Frankfurter 2017, fn. 54, citing, Saradi 1997, as also Haarman 1996, 612, on the similar uses of hieroglyph-inscribed blocks in medieval mosques.

${ }^{76}$ Dawes - Baynes 1948, Ch. 43, 44, 115, 116.

${ }^{77}$ Dawes - Baynes 1948, Ch. 115.

${ }^{78}$ Dawes - Baynes 1948, Ch. 116.
} 
ing idea occurred to some of the householders of the village; they came and opened the said chest and took off the covering, or lid, and carried it to their village and placed it there to serve as a water trough. Because of this many of the inhabitants of the village were again vexed by demons, and their beasts and properties were likewise injured. "'79 It was evidently well understood by the villagers in Galatia in the $6^{\text {th }} \mathrm{c}$. that such activities were liable to cause the release and infestation of unclean spirits-demons, illnesses and trouble to both man and beast of the village and to travellers throughout the region, and such activity, by accident or design, required, at times, the return of that which was taken, the infilling of the diggings-excavations, supplications and exorcisms by a holy man, a wonderworker. It was understood by many of the inhabitants of Ottoman territory both Rum and Muslim that ancient ruins and remains were to be left alone, even if they contained buried treasure. The numerous accounts of Jinn inhabiting old ruins, for Mus$\operatorname{lims}^{80}$; like the New Roman accounts relating that the ancient temples, ruins and mounds were full of fearful spirits in a variety of forms, likewise unintentionally led to the protection of the remains of antiquity. It was, in part $^{81}$, due to these demons and Jinn, understood to inhabit the remains of antiquity within the landscapes inhabited by Muslims and Christians that in the $15^{\text {th }}$ c. European merchant travellers such as Ciriacus of Ancona were able to record after the passage of more than a millennium, so much inscribed and carved material surviving from antiquity.

${ }^{79}$ Dawes - Baynes 1948, Ch. 118. See also Saradi 1997, 404-405, and, concerning re-use of pagan material in church construction so that the Christians would walk on the pagan remains, idem, 401, 403.

${ }^{80}$ For examples in Alf Layla wa-Layla, The Thousand Nights and One Night, in the Tales of, 'The King's Son and the Ogress,' in 'Ma'aruf the Cobbler', and in 'Qamar az-Zaman' with a Jinn in a Roman well: "It so happened that the chamber and tower were very old, and had been abandoned for many years. There was in the chamber an ancient Roman well in which dwelt a genie, one of the descendants of Iblis, the accursed one. Her name was Maymunah, and she was the daughter of Dimiryat, one of the famous kings of the Jinn. When Qamar az-Zaman had slept through the first watch of the night, the Ifritah rose out of the Roman well, intending to lie in concealment near the heavens in order to eavesdrop. When she reached the rim of the well, she saw a light burning..."; 'Abu Mahomed the Lazy,' "and hath informed me that there is in this city a talisman with which, if he desired to destroy all who are in the city, he could destroy them; and whatsoever he should order his Afrites to do, they would comply with his command; and that talisman is upon a pillar... She answered, 'It is the figure of an eagle, and upon it is an inscription which I know not." "In the name of Solomon," cried he (Habib), "and by virtue of his talisman, I command this bridge to be let down!" In a moment it began to move on its hinges... In the midst of the court stood a lofty column, on top of which was placed an iron cage. This pillar was covered with talismanic inscriptions. On the bottom was written, "Thou canst not be destroyed but by the power of Arabia." Habib struck the talismans with his sword." (Weber 1812, 194). It can also be noted that some Jinn were recorded as being imprisoned in stone columns by the Prophet Süleyman (The Extraordinary Tale of the City of Brass, Madinat al-nuhās) Madrus - Mathers II, 1996, 294. Frederick W. Hasluck (1973, 733) remarked: “The conception of Arab jinns who guard mysterious buildings, especially castles, or treasures, or both, is partly answerable for the recurring use of Arab in Turkish geographical nomenclature. Arab Hisar ('Castle of the Arab'), the ancient Alabanda, Arab Kulesi ('Arab's Tower') at Rhodes, Arab Euren ('Ruins of the Arab'), and possibly Arabkir are examples."

${ }^{81}$ Other factors were: the sheer quantity of ancient remains, blocks, slabs, columns, relative to the much reduced population inhabiting the site or in its vicinity following the 542-740 plague pandemic, together with a substantial decrease in the proportion of settled population and an increase in nomads, both factors reducing demand for construction materials; together with the increasing use of wood and lath and plaster in non-state construction. 
There were antique protective inscriptions, as well as sculptures and reliefs, some remaining in situ from antiquity, others subsequently deliberately placed in city walls, others over city gates. Procopius records that the longer version of the letter of Jesus Christ to Abgar the Black of Edessa was inscribed as a talisman and was placed over each of the city's gates for defence. ${ }^{82}$ In 806 the Abbasid Caliph Harun al Rashid is reported to have removed an inscription, a written stone supposedly having talismanic properties ${ }^{83}$, from over the gate of Heraclaea Cybistra-Ar. Hiraqlah-Ereğli. The whereabouts of this possibly Hittite inscription is today unknown. If it was removed, it was presumably transported onwards to Tarsus or to Raqqa, removed to be reused because it was understood to possess protective properties. Another source related it dated from 2,000 years earlier and was translated (in a non-literal manner) and was "copied", rather than removed. ${ }^{84}$ As late as the 1670's the Rev. John Covel noted that many city walls in Asia Minor still carried the protective inscription in Greek, "O Virgin, Mother of God, help this city." 85

${ }^{82}$ Procopius, Wars 2. 12. 20-30, "When the Christ saw this message, he wrote in reply to Augarus, saying distinctly that he would not come, but promising him health in the letter. And they say that he added this also that never would the city be liable to capture by the barbarians. This final portion of the letter was entirely unknown to those who wrote the history of that time; for they did not even make mention of it anywhere; but the men of Edessa say that they found it with the letter, so that they have even caused the letter to be inscribed in this form on the gates of the city instead of any other defence." Letters inscribed in stone serving like the icon of the Blessed Virgin hung for protection on the gate of Constantinople, at the time of the Avar attack on the city of 626 A.D.

${ }^{83}$ Hasluck 1973, I. 203, citing Hadji Khalfa (katib Çelibi), who mistakenly records Kal'at al-Salasil (Castle of the Chains)-Ancyra-Ankara, rather than Hiraqlah. Ankara was untouched in the 806 campaign.

${ }^{84}$ Klonsky 1974, 93, “The poet Chibl (ibn al-Shibl?), who served as interpreter in the Caliph's entourage, relates: Heraclea is surrounded by a ditch, with a high front gate that overlooks a ravine. Above this gate I noticed an ornamental stone with an inscription that went back more than 2000 years. I began to translate it aloud, unaware that the Caliph was standing close by watching me do so. Here is what it said: 'O son of man, seize opportunity of the present moment and abandon the vain striving for things that lie beyond you. Be careful lest the excess of your joy precipitate you into sin. Do not let yourself be overwhelmed by care for a day which has not yet come; for if destiny permits you to see that day, and if your life continues, God will provide for you. How many times has a man accumulated possessions for the future husband of his widow, or imposed privations on himself in order to enrich a stranger.' Harun was considerably moved by this inscription, and caused it to be written down in his book." The text recorded is a 'non-literal translation' of the inscription, with expressions such as, "God will provide for you.", almost certainly not dating from 2000 years earlier. Chibli was giving advice to the Caliph through this 'non-literal' reading of this inscription. A practice that may remind of the several inscriptions in Ionian characters translated by sheikh Abd al-Samad in The Extraordinary Tale of the City of Brass, Madrus - Mathers II, 1996, 288-291; 296-297, 300-301; as likewise, "amongst other things, three round jewels, big as ostrich eggs, from a mine of pure white gems whose like was never seen by man. Upon each were graven characts in Ionian characters, and they have many virtues and properties, amongst the rest that if one of these jewels be hung round the neck of a new-born child, no evil shall befall him and he shall neither wail, nor shall fever ail him as long as the jewel remain without fail.", likewise, "and over the doorway was a tablet whereon were graven letters of gold in the old ancient Ionian character."

${ }^{85}$ Covel, 1722, 376. His unpublished detailed observations of the walls of Constantinople, Seliori and Eregli and on epigraphy are in the British Library, at Covel Papers, Add. 32,912, 41-72; 75-112; 247-257. New Roman Miletus was also stated to have been protected by a magic inscription, Hasluck 1973, I. 203. 
Some inscriptions were understood to serve talismanic functions with telesmatic powers, others reminded of some prophetic association and, together with other objects, were employed to link the contemporary Muslim ruler with the power of antiquity. These understandings were 'reasonable,' valid within their own particular religo-cultural construct, if also quite distinctly different from the European antiquarian's recording of, and literal reading of the text of some of these same inscriptions, insofar as the non-European understandings had their basis in different, nonliteral "readings" of ancient inscriptions. In part, these non-literal "readings" were associated with the mysterious inscriptions that were attributed to Balinas (Balīnūs/Balinnās/Abūlūniyūs i.e., Pseudo-Apollonius of Tyana), as for example in the Kitáb at-Talásim al-Akbar (The Great Book of Talismans), a work in part based upon the late $5^{\text {th }}$ c. A.D. Greek pseudo-epigraph entitled, The Book of Wisdom of Apollonius of Tyana, translated from Greek into Arabic, Kitāb țalāsim Balinās al-akbar (The Great Book of Balinas' talismans) and Ethiopic ${ }^{86}$, then into Osmanlija; and also the Dhakhírat al-Iskandar (The Treasury of Alexander), a work said to have been presented by Aristotle to Alexander, and therefore of near prophetic status, given the association of Alexander the Great with the prophetic figure, Dhü'l Qarnayn-Zü'l Karneyn of the Qur'an, and the importance to Islamic rulers from the $12^{\text {th }}$ to the $17^{\text {th }} \mathrm{c}$. of titles such as Iskandar-i Sānī, the Second Alexander and Dhü'l Qarnayn al-Zaman, the Dhū'l Qarnayn of the Age ${ }^{87}$. The Treasury of Alexander, was translated from Syriac into Arabic and then into Osmanlija and it included a section on the use of talismans for healing. In the $6^{\text {th }} c$. John Malalas wrote that in Domitian's reign Apollonius paid a visit Byzantium, where he left many talismans in order to help the Byzantines in their troubles ${ }^{88}$ - and the understanding in Asia Minor was - that these talismans, which were usually made out of stone, including inscriptions on columns, or were of metal, were placed in cities and in city walls and on gates ${ }^{89}$ to protect the inhabitants against plagues, wild animals, vermin, natural disasters, evil spirits/non-believing jinn and such like, "with their mysterious inscriptions." "90 It was reported that King Qubad (Khusraw I. Anūshirwān

${ }^{86}$ Wallis Budge 1896, 355-385, Georgius Elmacinus, written also Elmakin, in his $13^{\text {th }}$ C. Majmu'-alMubarak. Relates: 'Now there are some who say that Aristotle the sage, the teacher of Alexander, taught the ten Sciences of the earth and established them, and that he composed many treatises on the healing of the body besides other well-known books. And he compiled for Alexander a work, which we have mentioned in a previous place, and entitled it "The Book of the Knowledge of the Laws of Destiny", and in it the Science of talismans and the art of astrology, and he drew therein magical figures which were to be used for frightening and terrifying men and he further gave instructions. . ' (idem. 382-383) 'And besides this he (Aristotle) wrote the book which is called "The Book of Astamatis" which treateth of the breaching of cities and fortresses and kings' houses and of the submission of kings, and of how men should make use of talismans and of the knowledge derived therefrom, and of the names which will bring down rain and water to them in the desert and in the Waste land, whensoever they utter them.' (idem. 384).

87 "Historians and various Qisas authors relate that al-Iskandar/Dhu'1-Qarnayn went to the ends of the world to demolish pagan temples, spread Islam, and protect the Muslims, as would be expected from a Muslim head of state." Milstein - Rührdanz - Schmitz 1999, 148.

${ }^{88}$ Dzielska 1986, 108.

${ }^{89}$ Malalas records that in Antioch he (Apollonius) set a talisman at the East Gate (i.e. north-east) against the north wind.

${ }^{90}$ In 1871, Murray's Handbook for Travellers in Constantinople, p. 85, relates: “Apollonius of Tyana erected several statues on the Hippodrome, and on the other public places of the city; and their mysterious inscriptions were interpreted as if they referred to the future fate of the city. Others were brought from Ath- 
531-579 A.D., Kisra) had Balinas-Apollonius of Tyana site a stone lion on one of the city gates of Hamadán as a talisman against the cold, and later, the Caliph Muktafi (902-908) wished to transfer it to Bagdad, but he was persuaded to leave it in place. ${ }^{91}$ Likewise, presumably to provide protection for the city, a pair of basalt carved stone lions of Hittite workmanship, seem to have been formerly displayed on the Islamic walls of the Harran citadel ${ }^{92}$; and it seems evident that the neo-Hittite stele found built into the top of a minaret of the Ulu Camii two miles to the west of Darende, was understood at the time of the minaret's construction to serve some important protective function; ${ }^{93}$ and there is an $8^{\text {th }}$ c. B.C. Hittite inscription carrying a dedication to the Storm-God, which was formerly employed face up, to form a step into the $16^{\text {th }} \mathrm{c}$. DışarıÇelebi Hüsamettin Bey mosque at Niğde. ${ }^{94}$ The subsequent reuse of these ancient sculptures and of inscriptions in a language then unknown, in these locations in mosques, clearly shows they were understood to carry a variety of meanings of importance for the Muslim inhabitants. Evidence indicating the importance in Ottoman eyes of talisman during the $16^{\text {th }}$ and $17^{\text {th }}$ centuries is recorded, in addition to the numerous talisman reported on and recorded as in situ by Evliya Çelibi in his $17^{\text {th }}$ c. Seyahatnâme; for example at the Ottoman siege of Oradea in Hungary in 1660 , the aim of the Ottoman gunners was to destroy the four $14^{\text {th }} \mathrm{c}$. bronze statues of Hungarian Saint-Kings, understood to have protected the city and which were said to have been responsible for the lifting of the Ottoman siege of Oradea two years earlier. The Ottoman gunners hit their targets in 1660, the talisman and the city fell. The bronze remains of these talismanic statues were then melted down and were cast into cannons that were then described as, "the gods of the Hungarians." ${ }^{15}$ It can be noted that Ottoman talismanic protective inscriptions were themselves at times carved in relief on marble spolia, with an example from Rhodes dated 987/1579, inscribed to protect Ottoman sailors and ships from dangers such as storms and to ensure safe passage,${ }^{96}$ other talismanic inscriptions, designed to protect Ottoman shipping from bad weath-

ens, Cyzicus, Caesarea, Tralles, Sardis, Sebastia, Satalia (Antalya), Chalcis, Antioch, Cyprus, Crete, Rhodes, Chios, Iconium, and Nicaea, these works of art were destroyed by the Latins, on the capture of Constantinople by Baldwin and Dandolo.", in the 1204 sack.

${ }^{91}$ Bargebuhr 2011, 126-127. There seems no reason to think the historical Apollonius of Tyana visited Hamadān (Ekbatana) by Mount Alvand and the association with King Qubad is chronologically adrift by more than half a millennium; but then matters of historical accuracy are of little import concerning past and present belief in spiritual connections and associations, as it was understood chronological time could be suspended or compressed to conform and illuminate a different set of chronologies and truths.

${ }^{92}$ Like the Hittite lion reused in the Halep citadel, http://gertrudebell.ncl.ac.uk/photo_ details.php? photo_id=2639.

${ }^{93}$ Garstang - Gurney 1959,31 . Also for example, the $13^{\text {th }}$ c. B.C. Hittite hieroglyphic inscription block built upside down into the Mamlūke mosque of Qaiqan, near the Antioch Gate of Aleppo, photographed in situ by Gertrude Bell, http://gertrudebell.ncl.ac.uk/photo_details.php?photo_id=2674.

${ }^{94}$ Hawkins 2000, 526-527. In this position it can be suggested it was employed and understood as marking for the worshipper the victory of Islam, of leaving the polytheist past behind, perhaps following the examples of the reuse of pagan inscriptions as threshold blocks at the entrance to churches, to be trodden on by Early Christian worshippers, e.g. Saradi 1997, 401, 403.

${ }^{95}$ Finkel 2005, 265.

${ }^{96}$ Tütüncü 2018, 13-17. 
er, were on-board Ottoman vessels in the $17^{\text {th }} \mathrm{c}$. as recorded by Jacques Gaffarel ${ }^{97}$. The importance over time of what were understood to be ancient talisman, 'written stones,' to Ottoman populations was considerable, as an incident from the $17^{\text {th }}$ c. shows. In May 1626 the English Ambassador to the Porte on behalf of the Levant company from 1621-1628, Sir Thomas Roe, in his final attempt to acquire four of the life-size stone reliefs of the Labours of Hercules still affixed by iron pins to Theodosius the Great's entryway to Constantinople, the "Chrysopule,"Porta Aurea, for 600 dollars in bribes ${ }^{98}$, the reliefs to be lowered and secured by the Great Treasurer, with these reliefs to be divided by lot between his two patrons, the Earl of Arundel and the Duke of Buckingham. ${ }^{99}$ But he was prevented from obtaining them after the news leaked, and a mob, possibly informed by the castellano of the Seven Towers, gathered preparatory to rioting, preventing their removal on the grounds that they were enchanted (talismans) and their removal would cause the fall of the city to the approaching Cossacks ${ }^{100}$ and its collapse into an underground cavern, as was said to be recorded "in an old book of prophesy." ${ }^{101}$ In the summer of 1626 the Cossacks raided the shores of the Bosphorus as far as Rumeli Hisar. ${ }^{102}$ This event followed a precedent recorded from 1204 by Robert de Clari, that "an old Greek told Walter the Templar"103 that the Latins would conquer Constantinople, because it was written on the Golden Gate, which had not been opened for two hundred years: "When the blond king of the West shall come, I will open of myself.", 104 itself a quotation probably recorded in a Greek book of talisman - "in an old book of prophesy," that stated the Latin inscription over the city gate foretold the fall of the citydynasty, combining the words for, destruction of a tyrant, gold, and golden, into a new nonliteral text. The $16^{\text {th }}$-century traveller Reinhold Lubenau, pharmacist to the Habsburg Imperial mission to the Porte of 1587-1589, related that there was a Byzantine gate in the city walls of

${ }^{97}$ See Bulmus 2012, 86, from the Ottoman use of talisman recorded by Jacques Gaffarel, Concerning the Talismanical Sculpture of the Persians; the Horoscope of the Patriarkes; and the Reading of the Stars, Trans. Edmund Chilmead, London 1650.

${ }^{98}$ Roe 1740, 444.

${ }^{99}$ Roe 1740 512, states a bribe of 500 dollars over three months, rather than 600 dollars (given in Roe $1740,444)$, a possible misreading of the handwritten numerals of these letters.

${ }^{100}$ Roe 1740, 512. Letter, May 1626, to the Duke of Buckingham.

${ }^{101}$ Possibly a reference to The Great Book of Talismans or a related work.

${ }^{102}$ Grodz 2016, 5.

${ }^{103}$ Not to be confused with the Templar, Walter of Mesnil, of 1173-4 fame/notoriety.

${ }^{104}$ Clari 1966, 111, also cited by Radulfi de Diceto, Stubbs 1876, 60. However, a transcription of the inscription was published in Rev. Smith 1707, 42, (Inside the main Portal) Hec loca Theudosius decorat post fata Tyranni, (Portal exterior) Aurea secla gerit, qui portam construit aure, cited from Sirmond, a somewhat different reading of this inscription; although Smith $1707 \mathrm{a}, 80$, gives a related account, " $A$ certain prophecy of no small authority runs in the minds of all the people, and has gain'd great credit and belief among them, that their empire shall be ruined by a Northern nation, which has white and yellowish hair. The interpretation is as various as their fancy.", Rev. Smith suggesting Muscovites (incl. Cossacks) and Swedes. It was known in the 1880's that the lost inscription on the portal exterior read: AVREA SAECLA GERIT QVI PORTAM CONSTRVIT AVRO, "he who builds a gate with gold rules a golden age." And inside the main portal, HAEC LOCA THEVDOSIVS DECORAT POST FATA TYRANNI "After the destruction of a tyrant, Theodosius adorned this place.", from the location holes for gilded bronze letters, Kelly 2012, 19. 
Nicea-Iznik and the inscription on this gate was understood by the Rum population inhabiting Iznik in the $16^{\text {th }} \mathrm{c}$., as recording an ancient prophecy of the forthcoming overthrowal of the ruling dynasty. The inscription over this gateway may in literal fact have recorded the name of the emperor Antoninus. ${ }^{105}$ This $16^{\text {th }}$ c. Rum interpretation of this inscription over this gate was brought to the attention of the Ottoman authorities and, in consequence, it was ordered that it be destroyed, and it was, so that the prophecy recorded in this 'non literal reading' of this inscription would be lifted, through the destruction of both the inscription and the gate supporting this inscription. ${ }^{106}$ It is therefore evident that the Ottoman state valued both the visible ancient inscriptions and the implications of the contemporary 'non-literal readings' of these ancient inscriptions, of the interpretations that were given to them.

The 'non-literal readings' of the inscription over the gate to Heraclaea Cybistra in the $9^{\text {th }}$ c., on the Golden Gate in the $13^{\text {th }}$ and $17^{\text {th }}$ centuries, as with the 'non-literal reading' of the Greek inscription on a gate at Nicaea in the $16^{\text {th }} \mathrm{c}$., not only indicate the significance and power that was understood to be embodied in any publicly displayed inscription and the respect/fear it generated, quite regardless of its age, script or language, or if it was actually readable in a literal sense by any of the inhabitants or not; as the 'non-literal reading' also reflected the shared understanding of the use of inscriptions in religious contexts, painted or inscribed, employed for protective and prophesying reasons, on and in, both Christian and Muslim structures. It indicated a worldview in which a publicly displayed inscription represented to the inhabitants much more than was simply indicated by reading the literal meaning of the individual words or signs employed in the inscribed text, and, at times, the fact that the script of an inscription was itself no longer literally legible, implicitly suggested it was a magical text, as noted by Hasluck, ${ }^{107}$ an inscription to be interpreted. The talismanic function given to both ancient inscriptions and "marbles" was understood and widespread, evinced by the reuse in Seljuk, Beylik and Ottoman structures of remains from antiquity, columns, inscriptions, reliefs, stone lions ${ }^{108}$ etc., regarded as evidence of the work of Balinas, as of the Prophet Süleyman/Solomon and the wonderworking Jinn, as also of Alexander-İskender, and as such, protective. It is noteworthy for example that the reuse of ancient and of New Roman remains in the construction of Seljuk hans, indicated that in these same locations there were earlier buildings that, given their isolated locations on routes and proximity to water sources, had served related functions, such as Roman mansio, and New Roman pandocheion, as has been noted, and it can also be suggested, that these remains were deliberately reused, not only because they were a ready source of building material in that location, but perhaps also because when incorporated into the new building they were understood to provide it with protection, both those spolien that may have been visible after construction was

${ }^{105}$ Two decades earlier Ogier Ghiselin de Busbecq-Busbequius had recorded at İznik, "Nicaea lies on the shores of the Lake of Isnik. The walls and Gates of the town are in fairly good condition. There are four gateways in all, and they can be seen from the central market-place. On each of them is an ancient inscription in Latin, stating that the town had been restored by Antoninus. I do not remember which Antoninus it was, but I am quite certain that it was an Antoninus, who was Emperor." Busbecq 1881, 136.

${ }^{106}$ Anderson 2015, 457.

107 Hasluck 1914, 62, “the fact that it has an inscription not 'understanded of the people,' and therefore assumed to be of a magical character."

${ }^{108}$ For the re-use of ancient lion sculptures in the Mihaloğlu Mehmed $16^{\text {th }} \mathrm{c}$. extension to shrine of Seyyid Gazi, and of their understood association with the Seljuks in the early $20^{\text {th }}$ c. see, Yürekli 2016, 140. 
completed, and those that lay concealed beneath the surfacing of plaster and paintwork, ${ }^{109}$ blocks carrying inscriptions pagan and Christian, were not defaced, but often placed face inwards ${ }^{110}$, upside down or on their side. Likewise ancient sculptures, reliefs and inscriptions were understood to have served a talismanic function when built into structures such as towers and city gates and city walls, like the ancient reliefs and sculptures built into the Seljuk rebuilt city walls of Konya, Antalya, Alanya, etc., or built into the walls of churches, and mosques, such as the antique lion built into the garden wall of the Arslanhane-Ahi Serafettin mosque in the Ankara citadel, or the Archaic Period lion set in the wall constructed of reused antique masonry blocks of the Aydinoğlu Mehmet Bey Mosque, Birgi of 1312, others built into the bases of minarets, etc. Some sculptures were converted, re-worked ${ }^{111}$, re-carved so they would be understood in a different way, while retaining some of their original characteristics, such as the front face of a Late Antique sarcophagus carrying a relief of two angels supporting, one may think, a XI/XI, a chi-rho Christogram, or a cross, in a roundel, which, nearly a 1000 years later was built into the outer face of the tower of the Great Citadel Gate in the Muslim Seljuk rebuilding of the city walls of Konya in c. 1221. The roundel with its monogram inscription or cross was infilled and the stucco infill was carved to represent the sun, symbol of the Divine Light, brought by the angels, and the two angels were given stucco haloes. Its employment perhaps served an additional purpose, in marking the tower as that constructed in this building program by the Rum Seljuk Sahib, Şemseddin İsfahânî, Şemseddin meaning the Light of the Religion. It can be suggested that it may also have been read by members of the Rum population of Konya as representing the clause in the Nicean Creed, 'God of God, Light of Light, Very God of God,' and it remained in situ into the $19^{\text {th }} \mathrm{c}$. when it was drawn by Léon Laborde in November $1825 .{ }^{112}$ (Figs. 1, 2) On these walls there were not only inscribed quotations from the Holy Qu'ran ${ }^{113}$ and the Shahname, ${ }^{114}$ but also a talismanic inscription which was said to have been commissioned by Sultan Ala ad-Din

${ }^{109}$ Duggan 2008 passim.

${ }^{110}$ For the ancient inscriptions placed face inwards in the Konya walls, the impression of the text remaining in relief on the dried mud in the core of the Seljuk walls, see, Greenhalgh 2013, 377, and references therein. It can be noted that for a talisman to operate, it was not necessary for them to be visible, they could be buried and remain effective, see for an example of this type: "On this particular case some light is thrown by the peasants' beliefs regarding a 'written stone' buried in a vineyard near Monastir: this was once dug up, but torrents of rain followed. It is now kept buried, because, if any one dug it up again, it would never stop raining." Hasluck 1973, I., 211, as in the same way people wore talisman shirts beneath their outer garments and carried talisman hidden in their garments. For examples of talismanic shirts covered in inscriptions worn by Ottoman sultans, see for example, Turks 2005, Z. Tanindi, Cat. Nos. 257, 322.

${ }^{111}$ For examples of the c. 1240 Seljuk reworking of Roman blocks in the facade, on the cornice of the pediment and in the conversion of the Roman relief of Dionysus in the pediment, into the Seljuk stucco relief of the naked Shirin recorded by Charles Texier in 1836 at the Belkis Palace at Aspendos, Duggan 2011. As also Kinnear's 1818 report on the Seljuk walls of Konya, "that statues and reliefs had missing arms and legs replaced." Greenhalgh 2013, 374, presumably in stucco, and presumably altering the meaning conveyed by these sculptures and reliefs to subjects more relevant to $13^{\text {th }} \mathrm{c}$. Seljuk culture, Feridun rather than Hercules, etc.

${ }^{112}$ Published in Laborde 1838, Pl. LXIV.

${ }^{113}$ Perhaps the "protective surahs," al-Falaq and an-Nas $(113,114)$.

${ }^{114}$ Ibn Bibi, Vol. I, 1996, 272-3. 
Keykubat I. from Jelal ad-Din Rumi, which was composed to protect the city walls ${ }^{115}$ and, within this context, it seems most probable that the inscriptions in ancient Greek, both visible and invisible in the reconstructed walls ${ }^{116}$ would have implicitly been associated with Balinas.

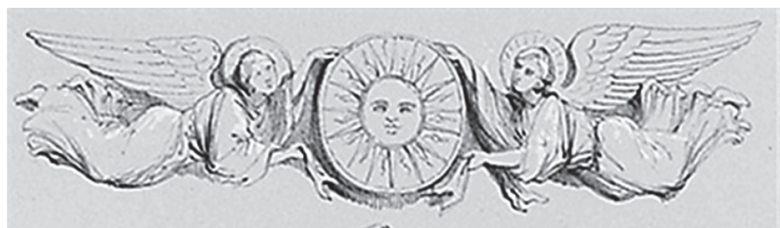

Fig. 1) Léon Laborde's November 1825 drawing of an Early Christian sarcophagus relief that had been re-worked and built into a tower of the Seljuk constructed walls of Konya c. 1221 .

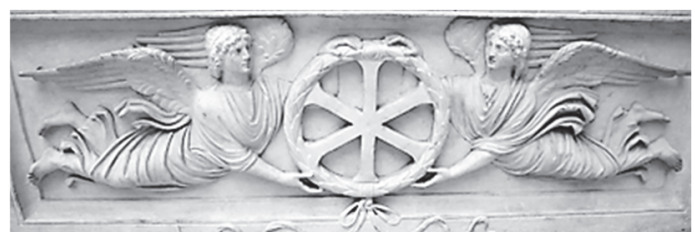

Fig. 2) Christian sarcophagus with XI/XI monogram, Constantinople, c. 400, of the Angels and Christogram type, of the type that was reworked and reused in the tower constructed as part of the Seljuk walls of Konya.

Sultan Süleyman Kanuni had the title "the Second Solomon" which is recorded on the endowment deed for the Süleymaniye mosque and this association was reinforced through the import for this mosque's construction between 1551 and 1557 of columns removed from Baalbek, a city said to have been built by the Prophet Sulayman's jinn and also from İskanderiyya-Alexandria, a city founded by İskander, and where, it was also related, "The jinn built an assembly hall for Solomon at Alexandria with 300 columns, each 30 cubits high, of variegated marble polished like mirrors, so that a man could see in them who was walking behind him. In the midst of the hall was a pillar 111 cubits high. The roof was a single block of green marble, square, hewn by the jinn." 117 Sultan Süleyman, the Sultan-Caliph was understood to be the Second Süleyman, the Alexander of the Age or Time, and so it can be understood that at times the re-used physical remains from antiquity, signified rather more than simply "old stones to new buildings,"118 the reuse of available building material - since some remains, columns ${ }^{119}$, were chosen, transported over consider-

${ }^{115}$ Hasluck 1973, I. 203.

${ }^{116}$ Leake 1824, 48-49.

${ }^{117}$ Butler - Fraser 1978, 387.

118 T. S. Eliot, 1940, Four Quartets, "East Coker.”

119 The relationship of columns/pillars in an Islamic context, as also, of columns, Solomon and the jinn has been little explored in the literature. However on the importance of columns-pillars Sahl al-Tustari ( $\mathrm{d}$. 896) related, "God created from its prostration (sajda) a mighty column (amud) like crystal glass (zujaj) of light that is outwardly (zahir) and inwardly (batin) translucent. It is from this Light of Muhammad, alTustarı adds, that the human race originated." (Akkach 2012, 94), and it may be the quest for ancient columns for reuse was more than simply a search for re-useable building material. It is noteworthy for example that the double-page frontispiece of the $15^{\text {th }} \mathrm{c}$. Ottoman Süleymānname painted for Sultan Beyazit II, has at the base, the depiction of jinn and columns, with some jinn shown chained to columns, Chester Beatty Library, Dublin, Ms. No. 406. A variant on the jinn chained to a black stone column by order of the Prophet Süleyman in The Extraordinary Tale of the City of Brass, "When I myself was taken, after a flight of three months, I was condemned to be fastened to the black pillar until the death of time itself." (Madrus - Mathers II, 1996, 294). Richard Burton has "Then they came upon a pillar of black stone like a furnace-chimney wherein was one (Jinn) sunken up to his armpits." Burton 1959, 445. "So Abdussemed drew near to the pillar and said to him who was therein, 'O creature, what is thy name and what art thou and how camest thou here on this wise?' 'I am an Afrit of the Jinn,' replied he, 'by name Dahish, son of El Aamesh," "and this pillar is my prison until judgement day." This relationship between jinn and 
able distances and deliberately incorporated into prominent positions in the construction of a new building - due to the understood associations with Süleyman and İskander, Solomon and Alexander, and the precious remains of their constructions, combined with the protection understood to have been afforded through the reuse of these ancient remains and associations, incorporated into the new construction, associations explicitly acknowledged by its $16^{\text {th }} \mathrm{c}$. patron, as being "the Second Süleyman."

Ancient inscriptions were understood to serve therapeutic purposes, when sat upon, healing fevers, malarial and rheumatic, aiding conception, etc.

The ancient Greek inscription on marble carrying a decree of Antiochus Soter of 278 B.C. from Sigeum-Ilium, which had been built into the porch of the church of Yenişehir-Janizari Cape, Giawr-keuy-Giaurkoi, was noted by the British Consul at Smyrna (1705-1715) Dr. William Sherard in 1702. ${ }^{120}$ This inscription was bought from the Greek priest by the English Ambassador to the Porte (1717-1718) Mr Edward Wortley Montague in 1718 and shipped to England and was presented by his daughter Lady Bute in 1766 to Trinity College Library, Cambridge, and is today in the Fitzwilliam Museum.

This inscription was regarded by the inhabitants as providing protection and healing and, following its removal, the protection that it was understood to provide was lost and the Rum population was immediately struck by the plague and the majority of the inhabitants died.

Concerning the Phanodikos inscription perhaps from 550 B.C. which was also built into the porch of the church wall of Giaurkoi, Sherard's dragoman Paulo Homero first transcribed it, it was then transcribed by Samuel Lisle and then by Bernard Mould ${ }^{121}$, and transcriptions of it and the Monumenta Teïa were sent by Consul Sherard to England, published by Edmund Chishull in 1728. ${ }^{122}$ In 1737 John Montague, the Earl of Sandwich remarked:

"In this village is a very valuable inscription, generally allowed to be the most ancient one this day extant. The people, who are proprietors of it, notwithstanding their extreme poverty, are resolved not to part with it upon any consideration whatsoever; having a superstitious tradition among

columns/pillars can be related to the hadith, "Said the Apostle of God (on him be prayers and peace), 'A certain demon of the Jinn attacked me yesterday in order to stop my prayers. But, verily, God gave me victory over him. I was about to tie him to the side of a pillar of the pillars of the Mosque so that ye might get up in the morning and behold him, all of you, when I remembered the prayer of my brother Solomon: "O Lord, forgive me and give me a dominion such as no one ever had,' and after that God set the demon free!" Columns-jinn are also frequently related to the "dust devils" and desert whirlwinds that carry sand or dust in the form of a column/pillar of prodigious height, said to be inhabited by jinn, "riding in the whirlwind," as in Alf Layla wa-Layla, the 1000 Nights and One Night, as likewise in the related phenomena of waterspouts. While in the course of pilgrimage, at Makkah, one of these pillars, near the Bab-az Ziadah, is known as the pillar of the Jinn, and there is the stoning of the pillars of Satan, while it is known that there are no columns supporting the heavens. The association of Solomon, jinn and columns pre-dates Islam, e.g. the line by the poet, al-Nābigha al-Dhubyānī, addressed to Solomon, "Exploit the jinn, for I have permitted them/ to build Tadmur [Palmyra] with iron and columns." Quoted El-Zein 2009, 41.

\footnotetext{
${ }^{120}$ On this see Jones 1993, 74.

${ }^{121}$ On this see Crawford 2003, 86.

${ }^{122}$ Chishull 1728, Monumenta TEIA, 102-138.
} 
them that upon the removal of another stone of the same kind (that removed by Edward Wortley Montague's party in 1718), the village was immediately attacked by a violent plague, which swept away the best part of the inhabitants. Had I imagined that I was likely to have better success than many others, who have endeavoured to tempt the people with considerable sums of money, I would have taken any method of procuring that valuable piece of antiquity." While Richard Chandler ignored the contemporary function of the inscription, which he described as "barbarism," wrote, "We copied these inscriptions very carefully, and not without deep regret, that a stone so singularly curious, which has preserved to us a specimen of writing antiquated above two thousand years ago, should be suffered to lie so neglected and exposed. Above half a century has elapsed, since it was first discovered, and it still remains in the open air, a seat for the Greeks, destitute of a patron to rescue it from barbarism, and obtain its removal into the far safer custody of some private museum, or, which is rather to be desired, some public repository." 123 Later the French Ambassador to the Porte from 1784, Gabriel Florent Auguste de Choiseul-Gouffier attempted to remove the Phanodikos inscription. He sought permission to remove it from the church in Yenişehir-Gavur Kioi, as "he claimed that the inscription was connected to an ancestor of his who had participated in the crusades," as though the inscription on the Phanodikos stele in Ionic and Attic dialects, dated from only 500 earlier, but, "He failed, notwithstanding the firmans of Hassan Pacha, who had aided him with all his influence over the Greeks:"124, due to the Rum inhabitants' opposition to the removal of this "healing" inscription. It was understood to be able to heal fever - malaria, as was known and recorded at the time. ${ }^{125} \mathrm{~W}$. Wittman and Sir R. Phillips who removed the inscription for the Earl of Elgin relate that the Bey Adamoğlu, "gave us a very civil reception, and supplied us with horses to proceed to the village of Giawr-keuy, or Janizari Cape, built on the site of ancient Sigaeum, and standing on an eminence which commands the plain of Troy. The purport of our journey thither was to procure a very curious bas-relief, and the celebrated Sigaean inscription, for Lord Elgin, who had seen them, and was desirous to transmit them to England. To accomplish this, a firman was procured from the Captain Pacha, who also furnished a chaous to be the bearer of it. We were not long in coming at these valuable antiquities, which we found at the entrance to a small Greek chapel. The Greeks, by whom the village was exclusively inhabited, were extremely averse to their being taken away. Their reluctance, we were told, arose from a superstition opinion they entertained, that by touching these stones agues were cured." 26 This inscription was "resorted to by the people for many miles around, from a belief that it was charmed, and had a power of curing such as sat upon it of the ague. The inscription was consequently in great danger of being rubbed away; when the marble was fortunately procured by Lord Elgin, and brought to England. The whole locality, it is said, was thrown into mourning by

${ }^{123}$ Chandler 1776, 38-39.

${ }^{124}$ Wittman - Phillips 1803, 66-67. It was also seen in place before its removal in 1799 by Prof. Rev. Joseph Dacres Carlyle (1758-1804) scholarly advisor to Lord Elgin's party.

${ }^{125}$ For an example of a similar healing inscription, see the Hittite hieroglyphic inscription built into the corner of a house at Hama, mentioned in 1812 by J. L. Burckhard, which "they believed, could cure diseases such as rheumatism if the sufferer touched them or rubbed against them." Morritt 2010, 348.

${ }^{126}$ Wittman - Phillips 1803, 66-67. They write "that by touching these stones agues were cured," while Hasluck 1973, I., 206, records, "patients were rolled on it, while the priest read an appropriate Christian exorcism." 
the loss of so venerable a relic." 127 It was of course for the inhabitants the loss of the healing properties of this talisman that threw the locality into mourning, not the loss of a venerable relic per se. The above clearly shows the different views of the inhabitants and European antiquarians concerning these grammata-written stones, respectively, "practical and functional," but described by Europeans as superstition or barbarism, or a "relic", to be copied and removed to the "safer custody of some private museum, or, which is rather to be desired, some public repository." The desire to obtain the original stone with its two inscriptions that had already been transcribed by William Sherard's dragoman Homeros in 1716, by the Rev. Samuel Lisle of the Smyrna factory and then by the subsequent chaplain Rev. Barnard Mould, and which had been published numerous times, not least by E. Chishull in $1728^{128}$, by Richard Chandler in $1775^{129}$, and then by Edmund Fry, in his Pantographia of $1799,{ }^{130}$ suggests something more akin to relic hunting, a fetish to possess, rather than simply a scholarly interest in the ancient inscriptions of recording and preserving the textual record from more than two millennia earlier.

There were other views held by Ottoman inhabitants concerning the ancient "written stones," inscriptions, they were not only, or all, regarded as protective and prophetic - talisman ${ }^{131}$ by the Muslim and Rum populations; some were healing inscriptions, upon which the sick sat or were laid, ${ }^{132}$ others were understood by many Turkish nomads, as still today, to give directions indicating the location of hidden treasure, as was noted by the Rev. James Dallaway c. 1795, "The Turks assign a singular reason for the curiosity travellers discover to examine all inscribed Stones, but this in particular (the Sigaean inscription) that it contains an exact account of the treasures secreted under the different burrows." 133

${ }^{127}$ Museum 1850, 366-367, re B. M. No. 107, today, No. 1002, Registration number: 1816,0610.107, Not on display. Today the B. M. catalogue entry, (Object reference number: GAA9341 sigaeum) strangely reports it was "excavated" by William Sherard (1659-1728), not that is was taken from the church porch on behalf of Thomas Bruce, the Earl of Elgin by Wittman and Phillips in 1799, and that it was bought for the British Museum by Act of Parliament, I ${ }^{\text {st }}$. July 1816 from the Earl, as also the Parthenon marbles, for

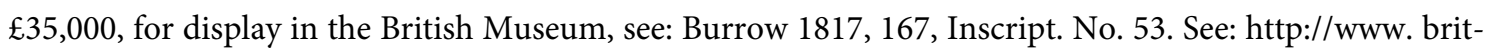
ishmuseum. org/research/collection_online/collection_object_details.aspx?objectId= 459473\&partId=1.

${ }^{128}$ Chishull 1728, “INSCRIPTIO SIGEA,” 1-48; C. L. Gr., 3595.

${ }^{129}$ Chandler 1774, 2-3.

${ }^{130}$ Fry 1799, 113-115, Greek 6, 7. "A splendid and expensive work has just been given to the world by Mr Fry, the letter-founder, under the title of Pantographia, containing accurate copies of all the known alphabets in the world; together with an English explanation of the peculiar force or power of each letter; to which are added specimens of all well authenticated oral languages; forming a comprehensive digest of Phonology. This is a very curious, and to scholars and philosophers a very important work. On the subject of the Greek alphabets and different modes of writing Mr. Fry seems to have bestowed particular attention; and he has in general followed able guides, such as Chishull, Montfaucon, \&c.” The Monthly Magazine: Or, British Register, Feb. 1799, 148-149, 149. Earlier Alexander Drummond had provided examples of Greek orthography, Drummond 1754, npn., before his First Letter.

${ }^{131}$ Being an artificial magical image, or figure.

${ }^{132}$ A practice likewise recorded in Ottoman Syria into the $19^{\text {th }}$ c., “The Hittites," 25-35, Blackwood's Magazine, Edinburgh, Vol. CXLII. July, No. DCCCLXI, 1887, 32.

${ }^{133}$ Dallaway 1797, 349-350. 
A further view in respect to an ancient Greek inscription was recorded by the Rev. Edmund Chishull, chaplain to the English factory at Smyrna from 1698-1702 ${ }^{134}$. The Muslim, Süleyman effendi's house in Magnesia had a stone staircase, with a reused block carrying an ancient Greek inscription forming one of the steps (Fig. 3). Edmund Chishull related, "the said effendi not only civilly informed us of the stone, but when we had transcribed the words, he proffered to send it after us to Smyrna; adding, that if it were any piece of sanctity, he was unwilling it should remain there to be trampled underfoot." 135 With, "any piece of sanctity" meaning in this context, if it carried a Christian inscription written by People of the Book, he did not want it to be trodden on, but offered to send it on to the Christians in Smyrna-İzmir, indicating respect for the words of the inscribed Greek text, if these were Christian.

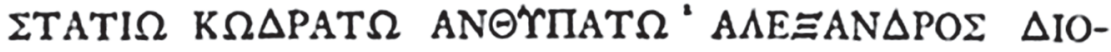

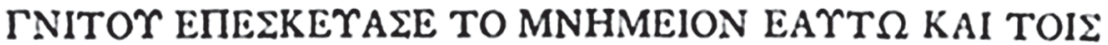

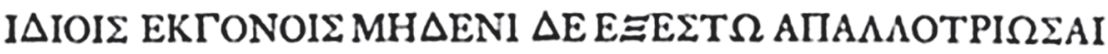

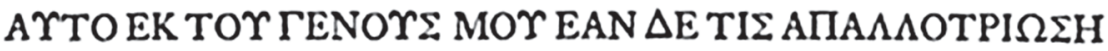

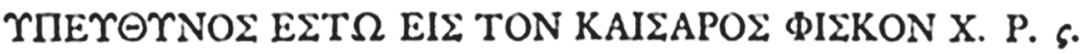

Fig. 3) Published transcription by Chishull of the ancient Greek text on the inscribed stone re-employed to form one of the steps of the staircase in Süleyman effendi's house in Magnesia Chishull 1747, 11. How many lines of text were inscribed is unclear, as also the shape of the epigraphic surface.

This same Muslim respect for sacred texts was recorded in the $18^{\text {th }} \mathrm{c}$. by M. Jean Otter of the Academy Royal of Inscriptions, "of a conference he had with a learned Persian. The Mahometan said, they reverenced all our sacred writings, except St. Paul's - qu'ils respectent tous, excepté Saint Paul." $" 136$

How safe a home was Europe for antiquities, including inscriptions and manuscripts that were brought from Asia Minor, and how much of scholarly importance was lost, at sea and on land?

During this period of 400 years antiquities, including inscriptions, were reused, defaced and destroyed in Asia Minor, some by natural events, earthquakes and tsunami, some due to human intervention, burnt in lime kilns, and reused as building material in construction works for sultans, villagers and others, including, for example, at the start of the $15^{\text {th }} \mathrm{c}$., the destruction of the tomb itself and the reuse of the stone blocks and reliefs of the earthquake damaged Wonder of the World, the Mausoleum of Halicarnassus, to construct the Castle of Petronium/San Pietro (Bodrum) by the Knights of St. John of Jerusalem on Rhodes; the extraction of lead from antique stone clamps to cast bullets, which resulted for example by the $16^{\text {th }} \mathrm{c}$. in the defaced parts of the lower sections of the Res Gestae Divi Augusti, ${ }^{137}$ and the ongoing reuse, not least of ancient columns for the construction of mosques and churches. But how safe a home was Europe for an-

\footnotetext{
${ }^{134}$ His notebooks are at B. M. Harlian Cat. N. 7509.

${ }^{135}$ Chishull 1747, 11-12.

${ }^{136}$ Warburton 1811, 120, citing, J. Otter, Voyage en Turque et en Perse, Paris 1748, Vol. I, 22.

137 "The top lines are nearly perfect; in the middle the gaps begin to present difficulties; the lowest lines are so mutilated with blows of clubs and axes as to be illegible. This is indeed a great literary loss, and one which scholars have much reason to regret; the more so as it is an ascertained fact that Ancyra was dedicated to Augustus as the common gift of Asia." Busbecq 1881, 142-143.
} 
tiquities, including inscriptions and manuscripts that were brought from Asia Minor, and how much of scholarly importance was lost at sea in transit and on land?

For example, "In the turbulent reign of Charles I. and the subsequent usurpation, Arundel house was often deserted by the illustrious owners; and in their absence, some of the marbles were defaced and broken, and others either stolen or used for the ordinary purposes of architecture. The chronological marble (The Parian Chronicle ${ }^{138}$ ) in particular, was unfortunately broken and defaced. The upper part, containing 31 epochas, is said to have been worked up in repairing a chimney in Arundel House." 139 Only a little over one half of the wisely selected inscriptions assembled by the Earl of Arundel at Arundel House, from Italy, Greece, from the Aegean Islands and from Asia Minor, some through his agent William Petty, 136 of the 250 important Greek, Latin and Hebrew inscriptions collected, including those from Smyrna-Izmir, survived the English Civil War to be presented to Oxford University in $1667 .{ }^{140}$ Losses included the upper part, lines 1 to 45 of the Parian Chronicle, an inscribed chronology extending from 1581/0 to 264/3 B.C. covering 1300 years of Hellenic history bought by William Petty in Smyrna-İzmir ${ }^{141}$. This near $50 \%$ loss of ancient inscriptions removed from their places of origin was passed over in silence in the ongoing rhetoric concerning securing antiquities in Ottoman territory from any possible destructive activities of the "barbarian" inhabitants. And concerning the Arundel Marbles, "various other fragments, which were not thought worth removing ${ }^{142}$, were buried in the rubbish and foundations of the houses in the lower part of Norfolk Street, and other buildings on the gardens. Several of these, including a few trunks of statues, dug up at a later time, were sent down to the

${ }^{138}$ The lowest section of the chronicle, the base of the inscribed stele was found on Paros in 1897.

139 s.v. 'Arundel,' Encylopaedia Britannica, Vol. II, 1810, 707. The suggestion it was used in this chimney building work, as also said to have been employed to repair a hearth-stone is quite uncertain, see on this Sandys 1908, 343. Henry Peacham in 1634 had described Arundel House "as the chief English scene of ancient inscriptions," Peacham 1962, 124, and it had been visited by King Charles I. and queen.

${ }^{140}$ Sandys 1908, 343; Tierney 1834, 484. The collection of 'marbles' before the Civil War consisted of 87 statues, 128 busts, and 250 inscribed marbles. The letter from John Evelyn to Henry Howard that resulted in the donation of the surviving inscriptions to Oxford University observed, "It is not without much regret and more concernment as it regards yr honourable and illustrious family, that I have now so long a time beheld some of the noblest antiquities in the world, and which yr grandfather purchased with so much cost and difficulty, lye abandoned, broken and defaced in divers corner about Arundel House and the gardens belonging to it. I know yr Honour cannot but have thoughts and resolutions of repairing and collecting them together one day; but there are in the meane tyme certaine broken inscriptions, now almost obliterated with age, and the ill effects of the weather, which will in a short time utterly be lost and perish, unless they be speedily removed to a more benigne and lesse corrosive ayre..." Evelyn 1827, 188. The house had been confiscated in the general confiscation made by the parliament, some of the marbles were then sold off to the Spanish ambassador Don Alonzo de Cardenas to The Lord Protector, Oliver Cromwell, and the house was finally returned to Lord Henry Howard in 1660 on the Restoration of the English monarchy.

${ }^{141}$ Several inscriptions brought in situ from Smyrna are recorded in Marmora Arundellina of 1628 including the inscribed column from the Temple of Venus Stratonicus.

${ }^{142}$ When Arundel House was demolished in 1678. 
Duke of Norfolk's seat at Worksop Manor.", ${ }^{143}$ while others, regarded as worthless and buried in the $17^{\text {th }}$ c. were recovered in $1972 .{ }^{144}$

While some of the antiquities including inscriptions that had been removed from Asia Minor to Europe were destroyed in conflict and disaster in Europe; others, including priceless manuscripts, inscriptions and sculptures, were lost in transit to Europe when vessels sank. The precedent was rather well known to antiquarians, being described by Cicero. Gaius Verres the Roman legate, had the shrine of Apollon on Delos looted, including removing its cult statue, and the ship transporting the loot sank ${ }^{145}$. But this precedent was ignored in the quest to obtain the original, for the possession of a venerable relic. Venetian notarial documents, two series of which were studied by Teneti in 1959 , show at the end of the $16^{\text {th }}$ and start of the $17^{\text {th }}$ c. there "were almost 40 shipwrecks along the route Constantinople-Venice in 17 years; that is at least two per year.", ${ }^{146}$ and the total loss of shipping per year throughout this entire period of 400 years on the several routes from Asia Minor to European ports was far greater than on this single route, some of which would have been carrying smuggled antiquities including epigraphic material when they sank. Contributory factors, such as the repeated dangerous overloading of English Levant Co. ships departing from Smyrna-İzmir for the captain's private gain in the $17^{\text {th }}$ century are also recorded. ${ }^{147}$ While searching for antiquities the Rev. William Petty in 1625, "In returning from Samos, he narrowly escaped with his life in a great storm, but lost all his curiosities, and was imprisoned for a spy; but, obtaining his liberty, pursued his searches."148 "he was released on the testimony of some Turks, who knew him, and that he had lost his credentials in the sea. With great industry he recovered his statues..." ${ }^{149}$ he "is gone to the place he left his boat to fish for his marbles" ${ }^{150}$ and he recovered the sunken marbles, ${ }^{151}$ and moved on to Ephesus, ${ }^{152}$ but any manuscripts he may have collected were lost, together with his berat, when the vessel sank. The Constantinople Patriarch Lucaris, friend of the Rev. Edward Pocock, was executed by strangulation in 1638 and the Patriarch's collection of rare manuscripts was rapidly removed by his longstanding friend, the Dutch resident Cornelius Van Haagen (1611-38), and dispatched to Holland, including the Greek manuscript of Clemens Alexandrinus's Hypotyposes, which the patriarch had brought from Alexandria to Constantinople, but the ship sank in a storm on the day of its

${ }^{143}$ S.v. 'Arundel Marbles,' Penny Cyclopaedia of the Society for the Diffusion of Useful Knowledge, Vol. II, No. 120, 1833, 427.

${ }^{144}$ Seven classical marbles were found during excavations on the site of Arundel House in the Strand in 1972, see Cook 1974, 247.

${ }^{145}$ Cicero, Against Verres, 2.1.46-48.

${ }^{146}$ Beltrame - Gelichi - Miholjek - Pavao 2014, 151.

${ }^{147}$ CSP 1860, 411.

${ }^{148}$ Caraccioli 1766, 219.

${ }^{149}$ Rees 1819, s.v. William Pettie - William Petty, the presumed translator from Greek of 1644 of The Commentary of George Aeropolita.

${ }^{150}$ Roe $1740,445$.

${ }^{151}$ Hervey 1921, 274.

${ }^{152}$ Roe 1740, 445. 
arrival in 1638 in Holland and the manuscripts were lost. ${ }^{153}$ It can be noted in respect to these losses that these were of collected, carefully selected and illegally removed antiquities. The problem of antiquities in transit shipwrecked continued: a part of the British Minister to the Court of the Two Sicilies in Naples from 1764 to 1800, Sir William Hamilton's collection of South Italian and Greek vases, was lost when it sank with HMS Colossus in 1798 off the Scilly Isles. 30,000 shards were recovered from a part of the wreck in the 1970's. ${ }^{154}$ The 'Mentor,' a polacre hired by Lord Elgin sank in 1802, the cargo of Parthenon marbles were recovered with the aid of sponge divers hired by William James Hamilton brought from Syme and Calymno over the course of two years ${ }^{155}$, but the collection of ancient Greek papyri scrolls made by Captain Leake was lost, together with his own maps and notebooks from his survey of Egypt. ${ }^{156}$ Other works were simply lost at some point in the course of their clandestine removal. For example the English Ambassador, Sir Thomas Roe wrote to the Earl of Arundel from Constantinople, in January 1621: "I have also a stone taken out of the old Palace of Priam of Troy, cut in a horned shape; but because I neither can tell of what it is, nor hath it any other beauty, but only the antiquity and truth of being a piece of that ruined and famous building, I will not presume to send it you; yet I have delivered it to the same messenger, that your lordship may see it, and throw it away." ${ }^{157}$ It is perhaps possible this stone cut in the shape of a horn was a work dating from the time of the Trojan War, a cult sculpture, but, whatever it was, it was lost, as the Earl of Arundel wrote in reply from London, Arundell House, December $9^{\text {th }} 1622$, to Amb. Roe: "I have received the Medall of Alexander which your Lordship (I thanke you) did send me, and I doe much valewe. For your stone, Your Master of the Shippe (Antony Wood, captain of the Rainbow) could not finde it, and I was yet lesse troubled for the wante of it, in respecte your Lordship wrote it had noe engraving upon it." 158

Text and Context: Problems in the transcription by hand of an inscription, of what was to be recorded and in the publication of an inscription in the period from 1550-1800.

\section{Problems with a transcription and in the recording of an inscription}

While some European antiquarians over these 400 years, transcribed inscriptions in visits to various parts of Asia Minor, largely in Aegean coastal regions and along major trade routes (Tables I, III), others just noted the presence of inscriptions in their publications. At Nicomedia in 1699 Sieur Aubry De La Motraye wrote, "As for inscriptions, I met none of them entire; and if Mr. Grelot, who says there are so many, had taken the Pains to communicate them, the Publick had

153 Twells 1740, 13, from which a synopsis given in, History of the Works of the Learned for the year One Thousand Seven Hundred and Forty, Article 29, For June 1740, London, 411. Likewise a bust of Hermes and other collected antiques were removed by the Spanish Amb. to Rome, Don Juan Domingo de Haro y Guzmán, viceroy of Naples 1683-87, but the whole collection is said to have been lost in the wreck of the vessel; while the treasures of the Albani Library in Rome, purchased by the Prussian Government were lost in a shipwreck off the coast of Gibraltar in 1863.

${ }^{154}$ CVA Great Britain 20 (British Museum 10).

${ }^{155}$ Memorandum, 22-23; Galt 1812, 138.

${ }^{156}$ Hamilton 1809, iv; 406; see also Wroth 1893, 324.

${ }^{157}$ Roe 1740, 16.

${ }^{158}$ Hervey 276. Perhaps meaning it was worth less in his eyes for not having any recognisable inscription on it. 
been more obliged to him, than for his singly saying so;" 159 Likewise, M. Le Roy in 1754 at Çardak Köy facing Gallipoli remarks, "et plusieurs inscriptions grecques curieuses," 160 but he doesn't record them; as likewise Thomas Hope on his extensive tour of Ottoman territory, who drew in coastal Lycia including the tombs at Antiphellus-Kaş in the early 1790's, wrote, "on the now almost deserted coast of Lycia, the thousands of sepulchral monuments, of an era apparently preceding its conquest by the Romans, and bearing Greek inscriptions.", ${ }^{161}$ but he doesn't transcribe them. There were unsurprisingly both inaccuracies and omissions in the transcriptions of the inscriptions that were published. For example George Sandy in his volume of Travels relation of a journey begun in 1610, first published in 1615, mentions Greek and Latin inscriptions on tombs at Troy ${ }^{162}$ but also provides no transcription of them, but he does provide a transcription of the Latin inscription on "Pompey's column" on the Cyanean Rocks at the entrance to the Black Sea. ${ }^{163}$ A later transcription of it was made by Jacques Spon \& George Wheler in 1675-6, ${ }^{164}$ another by Edmund Chishull on April $22^{\text {nd }} 1699^{165}$, another by the Earl of Sandwich in $1738 .{ }^{166}$ Each of these published transcriptions of the same Latin inscription, taken over the course of a century differs from the others, and by $1797, \mathrm{G}$. A. Oliver would write, "Several travellers have made efforts to read the Latin inscription which is there to be found; but the letters are at present so effaced, that it is difficult, perhaps even impossible, to accomplish that task." ${ }^{167}$

The problem with transcribing an inscription was not just the light, or its absence, the month and the time of day, the degree of shadow, its degree of visibility, the depth of incision, degree of erosion and encrustation, and time limitations in front of the inscription, as also its accessibility, as with the inaccessible inscriptions high up on the aqueduct by Ephesus, and, at some sites the sheer quantity of inscriptions, ${ }^{168}$ which amongst the hundreds needed to be recorded? But also, what the mind of the transcriber read into what he saw, which may not have been exactly what was to be seen on the epigraphic surface, the question of if the actual text of the transcribed inscription was corrected by its transcriber? Even in the copies made by Richard Pococke before 1752 of the careful transcriptions of inscriptions that had been made by Arthur Pullinger ${ }^{169}$,

\footnotetext{
${ }^{159}$ De La Motraye 1723, 213-214.

${ }^{160}$ Sevin 1802, 100.

${ }^{161}$ Hope 1835, I, 384.

162 Sandy 1673, Bk. I, 18.

${ }^{163}$ Sandy 1673, Bk. I, 32: DIVO. CAESARI. AUGUSTO. | L. CLANNIDIUS. | L. F. CLA. PONTO.

${ }^{164}$ Wheler 1682, Bk. II, 206-207, Restitution idem 207: DIVO CAESARI AVGVSTO | E CL. ANNIDIUS | L. F. CL. ARRONTO.

${ }^{165}$ Chishull 1747, 42: DIVO CAESARI AUGVSTO | L. CL. ANNIDIVS | L. F. CLAV. FRONTO.

${ }^{166}$ Sandwich 1807, 137: CAESARI AVGVSTO | CLANNIDIVS LF | CL FRONTO----- | ----CVR------.

167 Olivier 1802, 78.

168 Tournefort at Ankara citadel in 1701 writes, "This whole first enclosure is full of pedestals and inscriptions; but what part of Angora is without them? A good Antiquary would find what would employ a whole year to transcribe. We copied out the following," 15 inscriptions in both Latin and Greek" Tournefort, Vol. 111, 283. For other inscriptions transcribed at Ankara, idem, 287-288, in the battlements in Greek and Latin, idem, 291-294.

${ }^{169}$ Pullinger recorded the texts of over 100 Greek inscriptions, BM Mss. H. 4824.
} 
inaccuracies were introduced, which were then published in Pococke's IAGL, ${ }^{170}$ such as a single line inscription recorded by Pullinger at Ephesus in 1733, published as four lines by Pococke in 1752. ${ }^{171}$ The remarks made in the review by C. Merivale published in The Academy and Literature in 1874, concerning Theodore Bergk's 1873 edition entitled, Augusti rerum a se gestarum indicem cum Graeca metaphrasi, are to the point, "Throughout the last century the edition of Chishull (1728) was generally accepted as an adequate representation of the original. The inscription has been frequently examined since, and many emendations have been discovered or suggested." ${ }^{172}$ Comments also applicable to the slightly later, more accurate transcriptions made at the request of M. le Comte de Pontchartrain for King Louis XIV, by Paul Lucas ${ }^{173}$, of the Latin and the Greek texts of the Res Gestae Divi Augusti on this same building from $1^{\text {st }}$ to $21^{\text {st }}$ September 1705 , published in 1712. In terms of the accuracy of the transcriptions made in this period, of course they varied. W. M. Ramsay noted that ligatures are often misrepresented or ignored in transcriptions, and there is the frequent misreading of: $\Sigma$ for $\Xi$, of $\Lambda$ for $\mathrm{A}$, of $\Lambda$ for $\Delta$, O for $\Theta$, of $€$ for $\mathrm{C}$ etc. ${ }^{174}$ and a late form of $\Omega$ mistaken for O, and of K for IC, as by Paul Lucas. ${ }^{175}$ Chateaubriand describes this as, Lucas, "mangles all the inscriptions that he copies,..." ${ }^{176}$ Further, was it simply the inscribed text that was to be recorded? Was the task of the antiquarian simply the noting and collection through transcription of the surviving Greek and Latin texts, and the circulation and publication of these texts as texts, and at times their removal, an adjunct providing data for the more accurate writing of history? When did it begin to become something more than a text, involving the attempt to produce a scientific epigraphic record? Unsurprisingly the aims of individual antiquarians in Asia Minor over this 400 year period varied, the individual's specialities and interests differed, not least in respect to the text of inscriptions. Some mentioned but did not transcribe them, while others transcribed the inscriptions as texts, but a few others went further towards making a careful accurate record of both the text and its context, included recording the shape of the epigraphic surface, the letter forms employed and line breaks. Was the form of the epigraphic surface characteristic of a type, was there any relief carving? Was the epigraphic surface tall and narrow, or wide, or was it a narrow long surface. Was it inscribed on more than one side, on a column, or a post, or on the face of a rock outcrop etc., and were the lines of the text recorded with line breaks, were the different letter forms and sizes and the size of spaces between the letters and between the lines of the text noted? The text was distributed over what area, displayed at what height - were there any remains of surfacing and colour? Carved guidelines, incorrect letters, and other observations? Was any measurement taken? In other words, was only the abstracted transcribed text recorded, a block of text, or, was there an

${ }^{170}$ Noted and described, Drew-Bear - Naour - Stroud 1985, Part II, $13 \mathrm{ff}$.

${ }^{171}$ Drew-Bear - Naour - Stroud 1985, Part II, 23.

${ }^{172}$ Merivale 1874, 234. As earlier in the Athenaeum, No. 1335, May 28, 1853, 661, Rev. Beale Poste, Britannic Researches, "6. The Angora Inscription, part of which relates to Britain. The Latin of this was published by Chishull, the oriental traveller, in 1728, but was without sufficient authenticity,..."

${ }^{173}$ Paul Lucas relates that, although the text already existed in 'some authors', he had been sent to verify it. Voyage du Sieur Paul Lucas fait dans la Gréce, l'Asie mineure, la macédoine st l'Afrique, par ordre de Louis XIV, Paris 1712, I, 138-148, Greek, 308-313, Latin npn. at the end of vol. one.

${ }^{174}$ Ramsay 1918, 126-127.

${ }^{175}$ Ramsay 1918, fn. 76.

${ }^{176}$ Chateaubriand 1812, I., 39. 
attempt made to produce an accurate scientific record of the inscription, as an inscription? No publication of inscriptions from Asia Minor into the $19^{\text {th }} \mathrm{c}$., even those that published drawingsengravings of inscriptions, the approximation of a photograph, recorded all of the data expected today as standard: precise location, if in situ or not, measured size of object, size and form of epigraphic surface, stone type, spaces, letter size and forms, number of lines, etc.

\section{Publication and problems with the published printed representation of an inscription}

Ciriaco de Ancona/Pizzicolli's $15^{\text {th }}$ c. transcriptions of inscriptions were not published but circulated in manuscript copies but they often recorded in a drawing the shape of the epigraphic surface, the relative size of the letters and any relief carving.

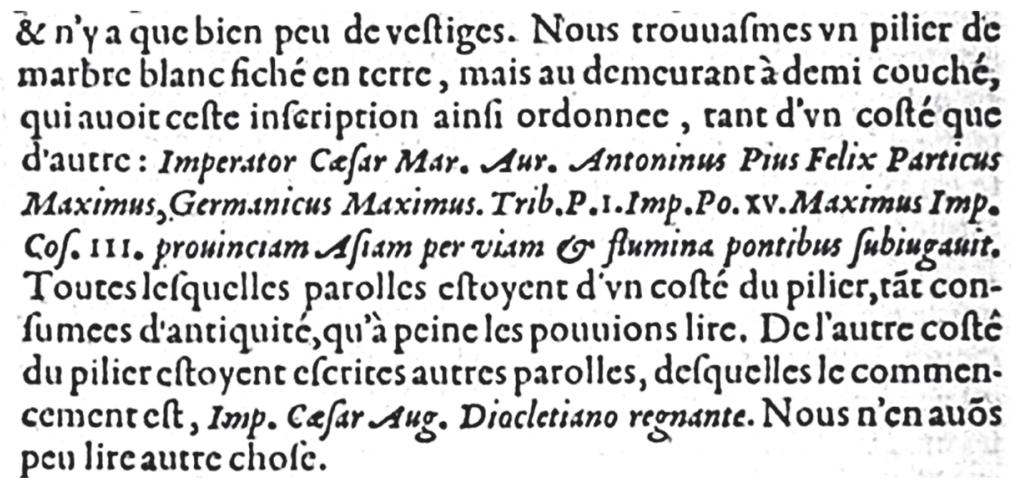

Fig. 4) Inscriptions, simply the text? Pierre Belon, Les observations de plusieurs singularitez et choses memorables trouvées en Grèce, Asie, Judée, Egypte, Arabie et autres pays estranges, 1553, T. II, Ch. VI, p. 582. ${ }^{177}$

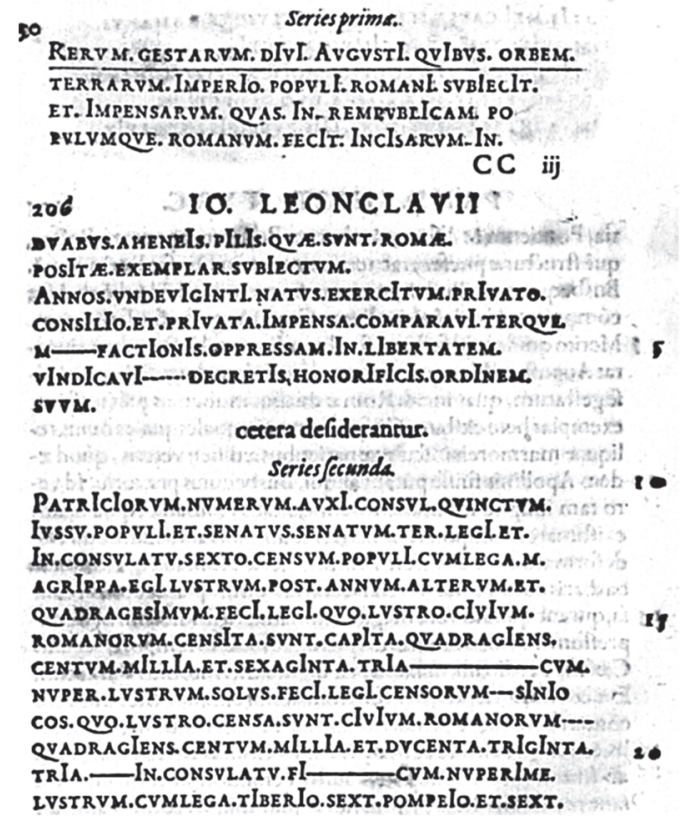

Fig. 5) Johannes Leunclavius's publication in Annales Sultanorum, A Turcis Sua Lingua Scripti, 1588, of the Res Gestae Divi Augusti, the opening lines, p. 205-6.
However, the few inscriptions transcribed in Asia Minor by Pierre Belon in 1546-9, were published as a Latin text in a standard font, without visual record of the context of the text of the inscription (Fig. 4), as likewise in publications of the Res Gestae Divi Augusti (Fig. 5), and this emphasis on the inscription as text was characteristic for the publication of inscriptions into the $18^{\text {th }} \mathrm{c}$. Strange as it may seem, in terms of the epigraphic information recorded, the drawings made by Ciriaco in the mid- $15^{\text {th }}$ c. often provide more accurate information than was practiced a century or two later in the printed publication of an inscription. As W. M. Ramsay stressed: "Another principal has to be constantly emphasised, that epigraphic copies reproduced in type are dangerous."; ${ }^{178}$ as later, for example with the use by the printer of J. R. S. Sterrett's, An Epigraphical Journey in Asia Minor, Papers of the American School of Classical Studies at Athens, II, Boston, 1888, of a typeface $₹$

\footnotetext{
177 Belon 1553, II, Ch. VI, page number typo, 582, should read page 182.

${ }^{178}$ Ramsay 1918, 125.
} 
rather than $\Sigma$, suggesting to the reader an earlier date for an inscription than is in fact the case. ${ }^{179}$

\section{Jacques Spon and George Wheler's different approaches and the mischievous Dr. Pickering's re- markable contributions}

Michael Werner wrote in 2011: "Jacques Spon was one of the most effective founders of an epigraphy for the Greek world. He justified the veritas and auctoritas of these new historical sources in the following words: "What is more, it is not as easy to invent or to falsify an antique inscription as it is to falsify a book or to supply it with a different, existing author: it takes great delicacy of spirit to recognize that a work was not written by a specific author. But I do not believe that it is so difficult to tell whether an inscription is not antique, if one has studied the matter a little. The stone that the Ancients chose, the form into which they cut it, and the exact shape of the letters combined with the depth that they gave it, all these things are not easy for the ignorant laborer to imitate." 180 However, disregarding the fact that these were not "new historical sources," as the use of epigraphic sources to confirm ancient literary sources, not least in relating antique toponyms to places, was practiced in the $14^{\text {th }}$ and $15^{\text {th }} \mathrm{c}$. by Early Renaissance scholars in Rome, Cola di Rienzo, Giovanni Dondi, Nicola Signorili, Poggio Bracciolini, Niccolo Niccoli, by Ciriaco de Pizzicolli, as by Konrad Peutinger in Augsburg, etc., and that an "ignorant labourer" would find it as difficult to imitate an antique text as an antique inscription; there is also at least one ancient Greek inscription from Asia Minor ${ }^{181}$ that was published by both Jacques Spon in 1678 and by George Wheler in 1682, that gave the public a non-existent inscription, supposedly inscribed on the façade of the Temple of Augustus at Mylassa-Milas. Wheler writes, "The first antiquity (of Mylasa) was a fair temple of marble, with an inscription on the front, shewing it was built in honour of Augustus Caesar, and to the Goddess of Rome." ${ }^{182}$ Dr Pickering ${ }^{183}$ (Docteur Picrelin ${ }^{184}$ ) had related his travel with Mr Salter to Mylasa-Milas in 1673 to George Wheler and Jacques Spon in Smyrna, and both then published copies of the drawing made by Dr Pickering showing this inscription (Figs. 6, 7,9), but there was in fact no inscription in this position on the facade ${ }^{185}$

\footnotetext{
${ }^{179}$ Ramsay 1918, fn. 28.

${ }^{180}$ Cited in translation, Werner 2011, 296.

${ }^{181}$ Spon, 1678, Bk. I, 362-363.

${ }^{182}$ Wheler 1682, Bk. III, 275. In translation, “The popular assembly (dedicated) to imperator Caesar Augustus, son of god, pontifex maximus, and to the Goddess Rome." My thanks to F. Onur for this translation.
}

${ }^{183}$ Medical doctor to the Smyrna factory, recorded inscriptions at Panionium, Miletus, Didyma, Askem Kalesi, Milas. Dr. Pickering was mentioned by William Cave, Smyrna Consul (1662-1667) in a dispatch printed in the Calendar of State Papers of $1^{\text {st }}$ of February, 1667: I "Fear that Dr. Pickering is drawing the youth of the Smyrna factory into gaming and debauchery, will not feel safe until he, his wife, and other vicious persons there without employment are out of Turkey." He was however regarded as a popular, amusing and jolly person by the Levant Co. members at Smyrna in 1675-6, and was thought to be a reliable source by Dr Spon and G. Wheler evinced by their publication of his records.

${ }^{184}$ Spon $1678,1,366$.

${ }^{185}$ This interpolation of an inscription on the frieze was not of the same order of scholarly manipulation of the evidence as the Abbé Fourmont's destruction of part of the epigraphic record of Sparta and Amyclae in 1730, with the fabrication of new epigraphic records, exposed by Richard Payne Knight in 1791, due to the use of the same orthography on inscriptions supposedly dating from the pre-Homeric 
(Fig. 8), it had been inserted by Dr Pickering. ${ }^{186}$ The inscription may have been elsewhere on site, perhaps on an altar, or was inspired by Livy 43. 6. 5. ${ }^{187}$, put into ancient Greek and added to the drawing of the facade to identify it.

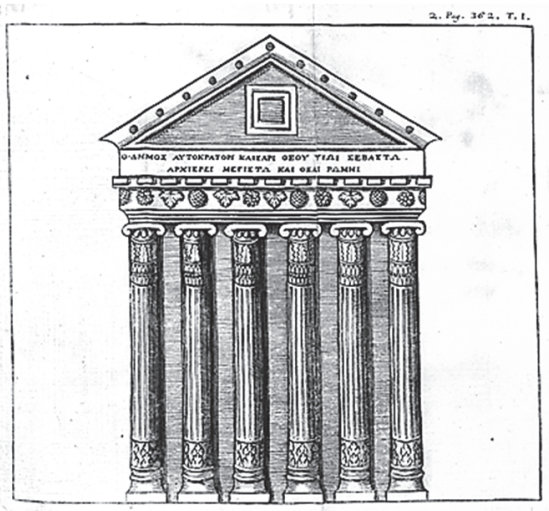

Fig. 6) Spon 1678, T. I, 362

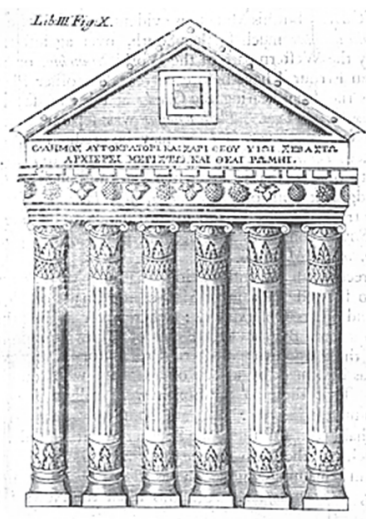

Fig. 7) Wheler 1682, Vol. III, Fig. X.

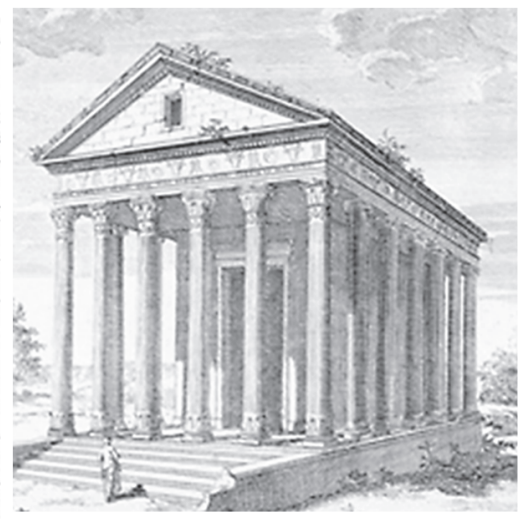

Fig. 8) R. Pococke's drawing of the temple in 1740, Pococke 1745, Pl. 55.

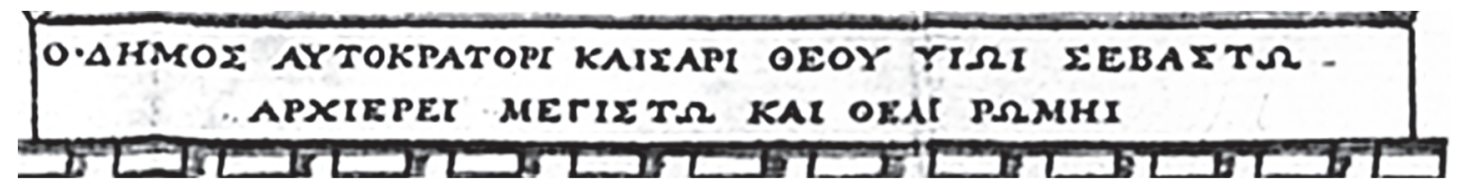

Fig. 9) Ancient Greek text of the dedicatory inscription placed on the facade by Dr Pickering, from Spon 1678.

\section{Just the Text, or the Inscription in its Epigraphic Context: Spon and Wheler}

Ioli Vingopoulou writes in respect to Jacques Spon of Lyon and George Wheler's works: "The three-volume account of Spon's voyage was first published in Lyon in 1678... while the third volume is dedicated exclusively to the inscriptions and coins collected by Spon during his journey. Spon's travel account was republished in French and was translated into English. Four years later, George Wheler published his own account of their journey, which is in fact but a mediocre copy of

into the Hellenistic period. See for example Payne Knight 1791, 113-114; Stoneman 2010, 99-106. But report of this "inscription" circulated, e.g. "3. At Mylassa, (formerly Mylasso in Caria), among other noble remains, are a magnificent marble temple, dedicated to the goddess of Rome, and built in honour of Augustus, as appears from an inscription, still entire, on the front,..." Sale et al. 1765, 27.

${ }^{186} \mathrm{R}$. Pococke's drawing of 1740 , pub 1745 , shows no inscription on the facade. It seems worth noting that by the time of J. B. Hilair's fine drawing of 1776, engraved and pub. in 1782, the temple had already been dismantled, "We were shown the basement, which remains; and we were informed, the ruin had been demolished, and a new Mosque, which we saw on the mountain-side, above the town, raised with the marble.", stated by Richard Chandler in 1765, Chandler 1776, 187. J. B. Hilair in his drawing simply copied and altered Pococke's drawing of the temple, removing the opening in the face of the pediment, which probably dated from the Late Antique conversion of the building, altering the proportions and the viewpoint of a building which he had not seen himself, in his drawing based on Pococke's, as the temple no longer stood.

187 "Alabandenses templum Urbis Romae se fecisse commemoravere ludosque anniversarios ei divae instituisse;". 
Spon's work." ${ }^{188}$ However, in respect to the publication of the same epigraphic material presented by both travellers, it was the botanist George Wheler's publication of 1682 that seems to have marked the essential change in the publication of transcriptions of antique inscriptions in Asia Minor, from the transcription of a text, towards the "scientific" recording of antique inscriptions, a novel undertaking, quite different from the usual publication of a transcribed text in the $16^{\text {th }}$ and $17^{\text {th }}$ centuries. Consequently, George Wheler's publication was very far from being "a mediocre copy of Spon's work," as in the publication of the same inscriptions, a great deal more epigraphic data is recorded in Wheler's publication than in the text provided by Spon, in part, it can be suggested, because Spon knew more, and so was concerned with the text and the meaning and commentary on the text itself, not with making a scientific record of the document's actual appearance on the epigraphic surface (see Figs. 10-17 for comparisons). George Wheler however records and shows the reader: the number of lines of the inscription and the relative sizes of the letters employed, with the sequence of letters, words and spaces in any line of an inscription. The shape of the "epigraphic surface' was itself delineated and the inscribed context displayed, as also, if the remains were incomplete through damage or being in part underground, then this was recorded. ${ }^{189}$ Unfortunately, no measurement of the epigraphic surface was given by George Wheler in his publication ${ }^{190}$.

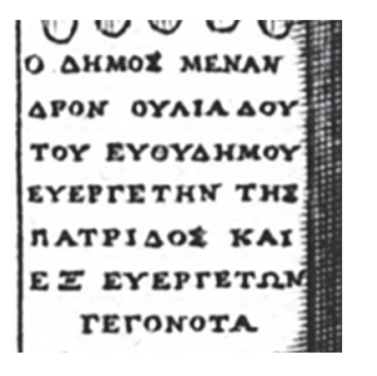

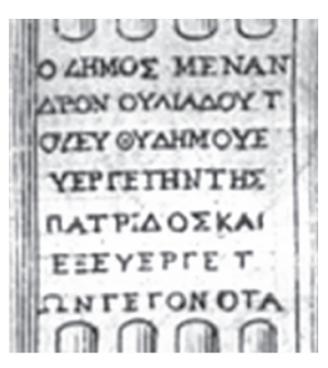

Figs. 10, 11) Copies of the inscription on the so-called 'pillar of Menander' by Mylasa, from Dr Pickering's original drawing of $1673^{191}$, were published differently by Spon (left) and by Wheler (right). Spon recording the text (Spon 1678, T.I, 362); Wheler recording the inscription, as recorded by Dr Pickering (Wheler 1682, Bk. III, fig. XII).

${ }^{188}$ Ioli Vingopoulou - Aikaterini Laskaridis Foundation, Athens, at: http://eng.travelogues.gr/travelo gue.php?view $=294 \&$ creator $=978920 \& \operatorname{tag}=8852$.

${ }^{189}$ Wheler 1682, Bk. III, 231, 232.

190 The publication of the measurement of the epigraphic surface was only remedied in some $19^{\text {th }} \mathrm{c}$. publications, for example M. G. F. A. de Choiseul-Gouffier, Voyage pittoresque de la Grèce, II, II, 1822, Pl. 38, both faces of an inscribed marble fragment found in 1814 at Tchiblak (by Troy) by M. Dubois and brought to France, are published drawn to scale, as are two fragmentary inscriptions from Alexandria Troas idem. II, II, 1822, Pl. 44.

191 The column and inscription was seen and recorded by Richard Chandler, Travels 1817, 216-217, Inscript. Ant. p. 27. 


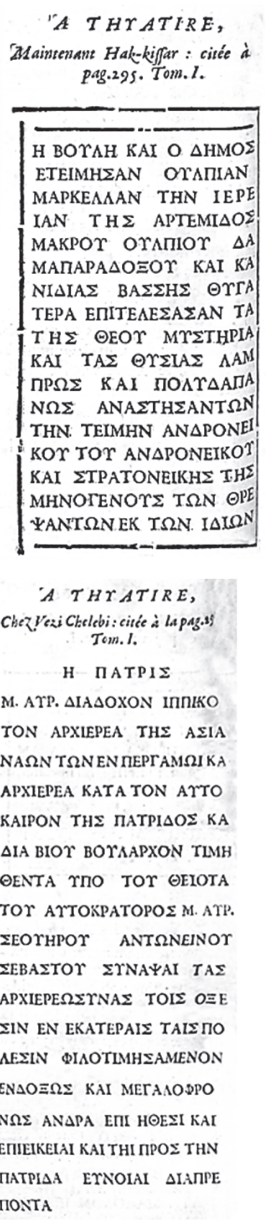

A SMYRNE,

Au Cemetiere des Armeniens. pag.310. Tom.l.

AГA@HI $\Upsilon \Upsilon \Upsilon \mathrm{HY}$

TH $\triangle$ AMПPOTATH KAI MH

TPOПO

$P \Omega T \Omega N \quad \Sigma E B A \Sigma T \Omega N$ KATA

TA $\triangle O$ OMATA THS IEP $\Omega T A$

TH $\Sigma \Upsilon \Gamma K \Lambda H T O \Upsilon \Sigma M \Upsilon P$

NAI $\Omega N \ldots .$.

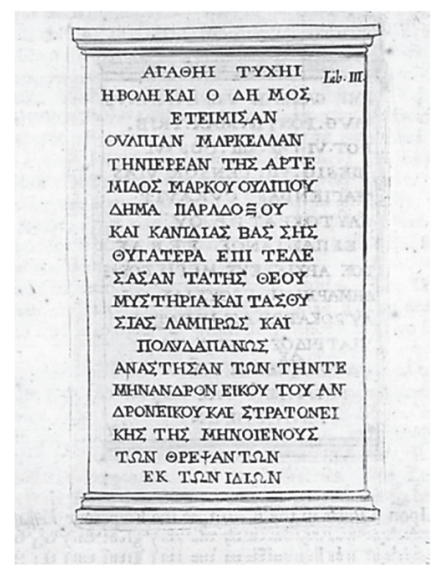

Figs. 12, 13) Copies of the same inscription at Thyatire/Thyatira/Akhisar by Spon (left) 17 lines and by Wheler (right) 19 lines. Spon recording the inscription as continuous text, first line missing; Wheler's recorded the lines of the inscription as it appeared on the epigraphic surface, with its form.

Figs. 14, 15) Copies of the same inscription at Thyatire/Thyatira/Akhisar by Spon (left) 19 lines and by Wheler (right) 16 lines. Spon's publication recording the inscription as text, Wheler's recording the inscription as seem on the epigraphic surface, with its form and with the relative letter sizes shown. All Spon's letters are of the same size.

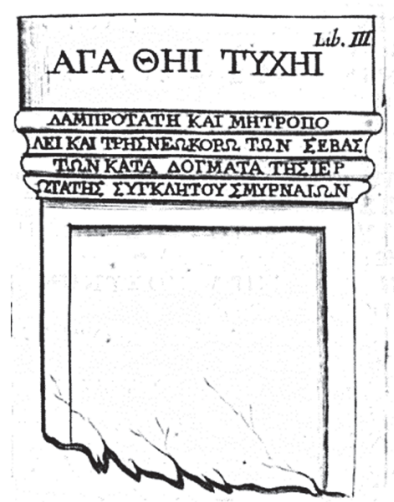

Figs. 16, 17) Copies of the same inscription at Smyrna by Spon (left) 7 lines and by Wheler (right) 5 lines. Spon's publication recording the inscription as text, Wheler recording the inscription as it appeared on the epigraphic surface, with its form, showing the number of lines and relative letter sizes. 


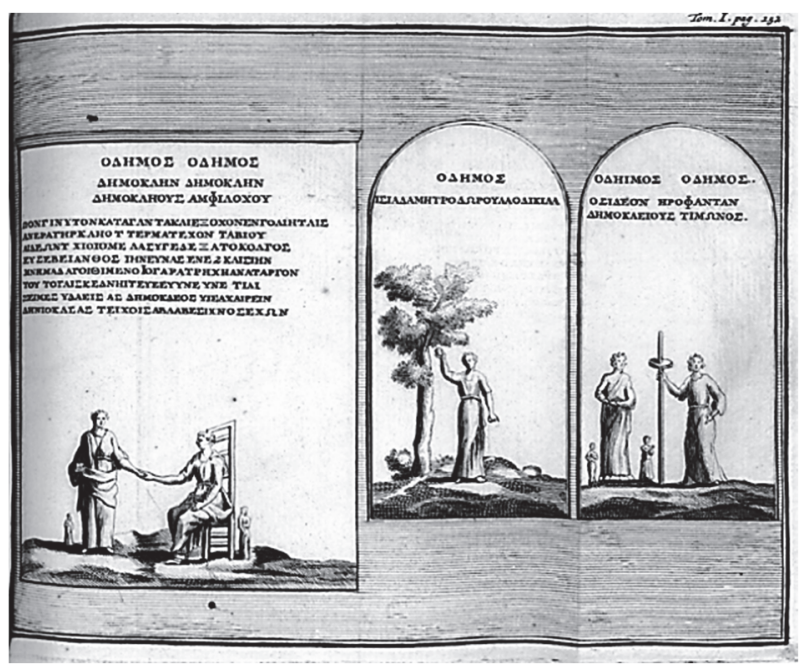

Fig. 18) The $18^{\text {th }}$ c. publication of three inscribed funerary and votive steles from Smyrna-Izmir. The published depiction of these inscribed steles with relief carving suggests attention was not paid to accurately recording either the inscriptions or the relief carving or the physical shape of these steles. Paul Lucas, Voyage $d u$ sieur Paul Lucas fait en MDCCXIV, \&c. par ordre de Louis XIV, dans la Turquie, l'Asie, Sourie, Palestine, Haute et Basse Egypte, \&c..., Amsterdam, 1720, T.1. p. 252. Paul Lucas collected on instructions from l'abbé Bignon, bibliothécaire $d u$ roi, and removed, in part to the French Royal Collection, at least 25 manuscripts, ${ }^{192} 55$ inscriptions and other epigraphic material Greek and Roman medals from Asia Minor.

Luigi Mayer Romano in the gouache drawings he made in Lycia in $1792^{193}$, some of which were published as aquatints in 1803 in his, "Views in the Ottoman Empire, Chiefly in Caramania, a Part of Asia Minor, hitherto Unexplored. With Some curious Selections from the Islands of Rhodes and Cyprus and the Celebrated Cities of Corinth, Carthage and Tripoli: From the original drawings in the possession of Sir R. Ainslie, taken during his embassy to Constantinople by Luigi Mayer: with Historical Observations, and Incidental Illustrations of the Manners and Customs of the Natives of that Country," records on Plate No. 3, entitled, Ancient Granary at Cacamo, a quite accurate copy of the Latin inscription extending along the cornice of the facade of the Roman horrea at Andriake ${ }^{194}$. But the transcription of the inscription was added to his drawing of the facade, which was not a measured drawing, and for reasons of legibility extends further along the facade than is actually the case, not least because Luigi Mayer records in his depiction seven, rather than the eight openings in the facade of the horrea, to centre the text and the carved relief Imperial busts over the "middle" door ${ }^{195}$.

192 "Lucas bought only twenty-five manuscripts, but specific ones - those missing from the king's collections." McCabe 2008, 131; including Bib. Nat. Paris 3118, a $17^{\text {th }}$ c. manuscript of Alf Layla wa-Layla acquired in 1718 .

193 Taylor 2013. It may be worthwhile for an epigrapher to look closely at the inscriptions depicted by Luigi Mayer in Sir Robert Ainslie's set of original gouaches of views of 1792, to determine which carry a legible datable epigraphic text. Recai Tekoğlu kindly looked at one for me depicted on a tabula ansata of a no longer extant sarcophagus at Kekova, and from the letter forms employed for the inscription it was Late Antique.

${ }^{194}$ Recorded in the Catalogue of Plates, description of Plate 3, "Horrea Imp. Caesaris Divi Trajani Parthici F. Divi Nerva; Nepotis Trajani Hadriani Augusti Cos. III," L. Mayer, Views in the Ottoman Empire, Chiefly in Caramania, ...R. Bowyer, London 1803 https://archive.org/details/gri_33125008694883/ page/n21.

195 The inscription is accurately depicted relative to the eight door openings in the facade in the scale drawing of the elevation drawn by J. P. Gandy, from the sketches and measurements he made on the 1812 Dilettanti mission, today in the RIBA, London, SD140/9, RIBA65811. 


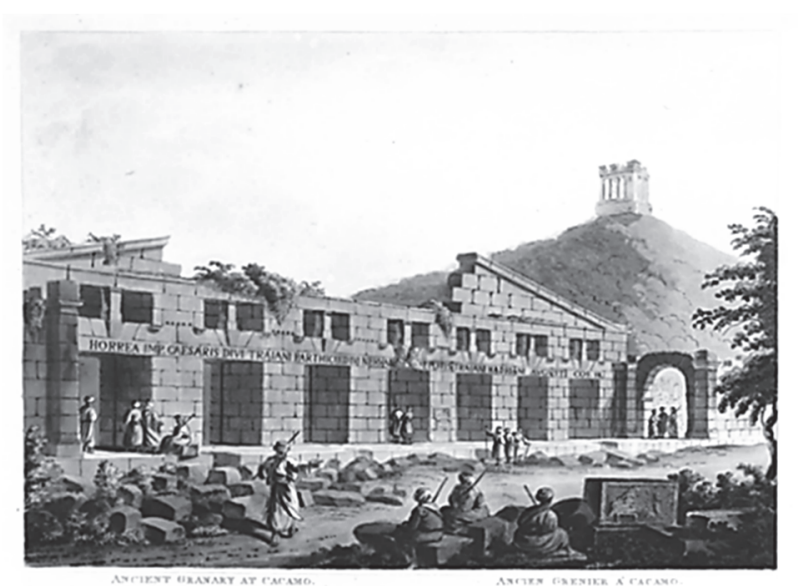

Fig. 19) Aquatint of Luigi Mayer's drawn record of $\mathrm{Ha}$ drian's horrea at Andriake of 1792, published in 1803, Plate 3. The inscription on the facade provides an accurate record of the text.

maining traces of colour and the support for it, and the applied surfacing and the colour of inscriptions and epigraphic surface, with very few exceptions, ${ }^{197}$ still today remains to be investigated through Raman spectroscopy etc.

\section{Conclusions}

Throughout these four centuries epigraphic material including inscriptions, coins, medals, carved gemstones, seals, intaglios and manuscripts, as well as sculptures and architectural elements, were illegally removed from Asia Minor to European collections, utilising for smuggling the numerous merchant vessels trading with Ottoman Asia Minor from Venice, Genoa, France, England and the United Provinces-Holland, some of which sank, while some selected epigraphic material was, after its arrival in Europe, mislaid, ill-used and destroyed. Antiquarian demand and the agents of European dealers and collectors who drove the hunt for antiquities including inscriptions in Asia Minor, as elsewhere in Ottoman territory over this period, and which resulted in incentives given to the poor to dig up ancient ruins and sites, rewarding successful looters, while destroying the context of the in situ finds that were made, established a precedent that continues today, and resulted in the collection of isolated relics, like the publication of individual epigraphic documents, isolated from their physical and epigraphic context. It can be stated that the activities of antiquarians in Asia Minor over the course of these four hundred years resulted in the transcription with varying degrees of accuracy and with varying quantities of textual and epigraphic information of some thousands of ancient Greek and Latin inscriptions,

196 French Academician François Arago (1786-1853) endorsed the new medium of photography in 1839 claiming it would provide a labour-saving means “... all will be struck by this reflection, that if photography had been known in 1798, we should this day have possessed faithful representations of many valuable antiquities now, through the cupidity of the Arabs, and the vandalism of certain travellers, lost for ever to the learned world. To copy the millions and millions of hieroglyphics which entirely cover the great monuments at Thebes, Memphis and Carnac, etc." (Daguerre 1839, 15).

${ }^{197}$ Duggan 2016. 
some of which remain of considerable importance for our understanding of antiquity and of ancient Greek and Roman epigraphy. The physical whereabouts of many of the inscriptions that were transcribed over these 400 years by antiquarians are today unknown. In the recording and in the publication of epigraphic material from Asia Minor in this period some advances were made, not least by George Wheler, in the change in antiquarian attention from a largely text based approach to an inscription towards a more epigraphic approach. The problems associated with the publication of transcriptions of ancient Greek inscriptions, not least the differences between the letter forms transcribed and the letter font employed in the publication of these transcriptions, formed an impediment at times to dating, correct reading and the understanding of some inscriptions published during this period, as was noted a century ago by W. M. Ramsay. ${ }^{198}$ Further, the precedent established by antiquarian practice over the course of these four centuries, of transcribing, publishing and commenting upon individual texts-inscriptions, in part because many had been reused, although valuable of itself, has tended to obscure the wider physical context of these individual documents in antiquity when in situ, the importance of the epigraphic context of inscriptions in particular locations within ancient cities and sites and the question of the reasons why epigraphic documents were placed where they were, how they were noticed and read in antiquity, not then being seen as individual inscriptions in isolation from the surrounding epigraphic material and their physical context.

\section{Bibliography}

Akkach 2012

S. Akkach, Cosmology and Architecture in Premodern Islam: An Architectural reading of Mystical Ideas, New York 2012.

Anderson 2015

B. Anderson, "An alternative discourse": Local interpreters of antiquities in the Ottoman Empire, Journal of Field Archaeology, 40/4, 2015, 450-460, DOI: 10.1179/2042458215Y.0000000017.

Anon. 1800

Anonymous, Extracts from the Journal of an anonymous Traveller in the Vicinity of Smyrna, preserved in the British Museum. Harl. Mss. 7021, 182-188, in: The Oriental Collections: consisting of Original Essays and Dissertations, Translations, and Miscellaneous Papers, Illustrating the History and Antiquities, the Arts, Sciences, and Literature, of Asia, Vol. III, For January, February, and March, 1799, Debrett, London 1800.

Ball 1729

J. Ball, The Antiquities of Constantinople: With a description of its situation, the conveniencies of its port, its publick buildings, the statuary, sculpture, architecture, and other curiosities of that city. With cuts explaining the chief of them. In four books, London 1729.

Bargebuhr 2011

F. P. Bargebuhr, The Alhambra: A Cycle of Studies on the Eleventh Century in Moorish Spain, (1968) 2011.

Belon 1553

P. Belon, Les observations de plusieurs singularitez et choses memorables trouvées en Grèce, Asie, Judée, Egypte, Arabie et autres pays estranges, II, 1553.

Beltrame - Gelichi - $\quad$ C. Beltrame - S. Gelichi - I. Miholjek - S. Pavao, Shipwreck: A 16th

${ }^{198}$ Ramsay 1918, 125. 
Miholjek - Pavao 2014

Bibi 1996

Bulmuş 2012

Burrow 1817

Burton 1959

Busbecq 1881

Butler - Fraser 1978

Cadwallader 2014

Chandler 1774

Chandler 1776

Chateaubriand 1812

Chishull 1728

Chishull 1747

Clari 1966

Cook 1974

Covel 1722

Crawford 2003 century Venetian merchantman from Mljet, Croatia 2014.

Ibn Bibi, el-Hüseyin b. Muhammed b. Ali el-Ca'feri er-Rugadi. M. Oztürk (çev.), El Evamiru'l-Ale'iye Fi'l-Umuri'l-Ala'iye (Selçukname), Vol. I, Ankara 1996.

B. Bulmuş, Plague, Quarantines and Geopolitics in the Ottoman Empire, Edinburgh 2012.

Rev. E. I. Burrow, The Elgin Marbles: with an Abridged Historical and Topographical Account of Athens ... Vol. I. Illustrated with Forty Plates Drawn and Etched by the Author, London 1817.

R. Burton, The Arabian Nights: An Adult Selection, New York 1959. Busbecq 1881, The Life and Letters of Ogier Ghiselin de Busbecq, seigneur of Bousbecque Knight, Imperial Ambassador, C. T. Forster - F. H. Blackburne Daniell, Vol. 1, London 1881.

A. J. Butler - Ed. P. M. Fraser, The Arab conquest of Egypt and the last thirty years of the Roman dominion, Oxford (1902) 1978.

A. Cadwallader, History as Bulwark, Bridge and Bulldozer: Dei Verbum and Ecumenical, Biblical Endeavour, 207-224, in: Eds. M. O'Brien - C. Monaghan, God's Word and the Church's Council: Vatican II and Divine Revelation, 2014.

Rev. Dr. R. Chandler, Inscriptiones Antiquae, Oxford 1774.

Rev. Dr. R. Chandler, Travels in Asia Minor, Or an Account of a Tour Made at the Expense of the Society of Dilettanti, London (1775) $1776^{2}$.

Travels in Greece, Palestine, Egypt, and Barbary During the Years 1806 and 1807 by F. A. de Chateaubriand; Translated from the French by Frederic Shoberl, in Two Volumes, Vol. I, London 1812.

E. Chishull, Antiquitates Asiaticae christianam oram antecedentes, ex primariis monumentis graecis descriptae etc. London 1728.

Rev. E. Chishull, Travels in Turkey and Back to England, by the Late Reverend and Learned Edmund Chishull, Chaplain to the Factory of the Worshipfull Turkey Company at Smyrna, London 1747.

R. de Clari, The Conquest of Constantinople, Ed. E. H. McNeal, 1966.

B. F. Cook, The Classical Marbles from the Arundel House Site, WC2 in 1972, 209-248 in: London and Middlesex Archaeological Society, Vol. 26, London 1974.

J. Covel, Some Account of the Present Greek Church, with Reflections on their Present Doctrine and Discipline, Particularly in the Eucharist, And the rest of their Seven Pretended Sacraments, Compared with Jac. Goar's Notes upon Greek Ritual, Euchologion, Cambridge 1722.

M. Crawford, William Sherard and the Prices Edict, RN 2003, 83- 
CSP 1858

CSP 1860

CVA

Daguerre 1839

Dallaway 1797

Dawes - Baynes 1948

de Bruijn 1700

de Jonge - Ottenheym 2007

Dibdin 1810

Dobree - Scholefield 1835

Drew-Bear - Naour Stroud 1985

Drummond 1754
107.

Calendar of State Papers, Domestic Series, Charles I (1625-1649), Ed. M. A. E. Green, Vol. 1, PRO, London 1858.

Calendar of State Papers: Of the Reign of Charles II., Domestic series, (1660-1670), Ed. M. A. E. Green, Vol. X, PRO, London 1860.

Great Britain 20 (British Museum 10).

History and Practice of Photogenic Drawing on the True Principles of the Daguerréotype, with the new method of Dioramic Painting; Published by order of the French Government. By the Inventor L. J. M. Daguerre, with notes and explanations, by M. Arago, etc. Translated by J. S. Memes, London 1839.

J. Dallaway, Constantinople Ancient and Modern: With Excursions to the Shores and Islands of the Archipelago and to the Troad, London 1797.

E. A. S. Dawes - N. H. Baynes (edd.), Three Byzantine Saints: Contemporary Biographies of St. Daniel the Stylite, St. Theodore of Sykeon and St. John the Almsgiver, trans. Elizabeth Dawes, and introductions and notes by Norman H. Baynes, Basil Blackwell, Oxford 1948. https://sourcebooks.fordham.edu/basis/theodoresykeon.asp.

Cornelius de Bruijn, Voyage au Levant, c'est a dire Dans les Principaux endroits de L'Asie Mineure, ..., Traduit de Flamand, Delft, Henri de Kroonevelt, 1700 http://gallica.bnf.fr/ark:/12148/bpt6k853 30k/f2. Image.

K. de Jonge - K. Ottenheym (edd.), Unity and Discontinuity: Architectural Relations Between the Southern and Northern Low Countries 1530-1700, Turnhout 2007.

Typographical Antiquities: Or the History of Printing in England Scotland and Ireland: containing memoirs of our Ancient Printers, An A register of the Books Printed by Them. Begun by the Late Joseph Ames ... Considerably Augmented by William Herbert ... and Now Greatly Enlarged ... by the Rev. Thomas Frognall Dibdin, Vol. 1, London 1810.

P. P. Dobree - J. Scholefield, Miscellaneous notes on inscriptions. By Professor Dobree, With some addenda to his Adversaria, Ed. J. Scholefield, Cambridge 1835.

T. Drew-Bear - C. Naour - R. S. Stroud, Arthur Pullinger: An Early Traveller in Syria and Asia Minor, Trans. Am. Phil. Soc. New Series, Vol 75. No. 3, 1985, 1-80.

A. Drummond, Travels Through Different Cities of Germany, Italy, Greece and Several Parts of Asia, as the Far as the Banks of the Euphrates, in a Series of Letters... by Alexander Drummond, Esq., H. 
Duggan 2008

Duggan 2011

Duggan 2012

Duggan 2015

Duggan 2016

Dzielska 1986

Elmes 1824

Evelyn 1827

Finkel 2005

Foss 1976

Frankfurter 2017

Fry 1799

Galignani 1822

Galt 1812

Garstang - Gurney 1959

Gassendus 1657

\section{Consul Aleppo, London 1754.}

T. M. P. Duggan, The Paintwork and Plaster on Evdir and Kirkgöz Hans by Antalya-and some implications drawn concerning the original appearance of $13^{\text {th }}$ c. Seljuk State Buildings, Adalya XI, 2008, 319-358

T. M. P. Duggan, An interpretation of some unpublished in situ and recorded Rum Seljuk $13^{\text {th }}$ c. external and internal figural relief work on the Belkis (Aspendos) Palace, Antalya, Gephyra 8, 2011, 143-184.

T. M. P. Duggan, Liman Kenti Satalya'daki (Antalya), Şeyh Ahmed Bedevi/Vaftizci Yahya ve Başmelek Cebrail Rölyefleri, Toplumsal Tarih, Ağustos 2012, 56-61.

T. M. P. Duggan, Due Diligence and the Treaty of 46 B.C., Libri 1, 2015, 59-70.

T. M. P. Duggan, Not just the Shadows on the Stone: the Greek, Lycian and Roman Craft of Encaustica ( $\left.\varepsilon^{\prime} \gamma \kappa \alpha v \sigma ı \varsigma\right)$ and the Polishing ( $\gamma \alpha \dot{\alpha} \omega \omega \sigma \iota)$ ) of Coloured Inscriptions, that is, of Graphō ( $\gamma \rho \alpha \dot{\varphi} \varphi \omega)$ and its Study - Epigraphy, Phaselis II, 2016, 269-283.

M. Dzielska, Apollonius of Tyana in Legend and History, Trans. P. Pienkowski, L’erma di Bretschneider, Rome 1986.

J. Elmes, A General and Bibliographical Dictionary of the Fine Arts..., Part I., T. Tegg, London 1824.

Memoirs of John Evelyn, Esq. F. R. S., Epistolary Correspondence, Ed. W. Bray, Vol. IV, London 1827.

C. Finkel, Osman's Dream: The Story of the Ottoman Empire 13001923, London 2005.

C. Foss, Byzantine and Turkish Sardis, Vol. IV, Archaeological Exploration of Sardis (1958-), Harvard 1976.

D. Frankfurter, Christianizing Egypt: Syncretism and Local Worlds in Late Antiquity, Princeton 2017.

E. Fry, Pantographia: Containing Accurate Copies of All the Known Alphabets in the World; Together with an English Explanation of the Peculiar Force or Power of Each Letter: to which are Added, Specimens of All Well-authenticated Oral Languages forming a comprehensive Phonology, London 1799.

Ancient Sculptures in the British Museum, Sunday, Jan. 27th, Galignani’s Literary Gazette, Vol. XIV, 1822, 92-94.

J. Galt, Voyages and travels in the years 1809, 1810 and 1811, containing observations on Gibraltar, Sardinia, Sicily, Malta, Scrigo and Turkey, London 1812.

J. Garstang - O. R. Gurney, The Geography of the Hittite Empire, BIAA, London 1959.

P. Gassendus, Englished by W. Rand, The Mirrour of True Nobility 
Gibbon 1788

Greenhalgh 1989

Greenhalgh 2009

Greenhalgh 2013

Grodz 2016

Gunning 2016

Haarman 1996

Halbertsma 2003

Hamilton 1809

Hasluck 1914

Hasluck 1973

Hawkins 2000

Hervey 1921

Hope 1835

İnalcık 1997

Jones 1993 and Gentility. Being the Life of The Renowned Nicolaus Claudius Fabricius Lord of Peiresk, Senator of the Parliament at Aix, Bk. IV, London 1657.

E. Gibbon, Decline and Fall of the Roman Empire, Vol. VIII, London 1788 .

M. Greenhalgh, The Survival of Roman Antiquities in the Middle Ages, Duckworth 1989.

M. Greenhalgh, Marble Past, Monumental Present: Building with Antiquities in the Mediaeval Mediterranean, Leiden 2009.

M. Greenhalgh, From the Romans to the Railways: The Fate of Antiquities in Asia Minor, Leiden-Boston 2013.

S. Grodz, Introduction, 1-15 in, Christian-Muslim Relations. A Bibliographical History, Vol. 8. Northern and Eastern Europe (16001700), Leiden 2016.

L. P. Gunning, The British Consular Service in the Aegean and the Collection of Antiquities for the British Museum, London 2016.

U. Haarman, Medieval Muslim Perceptions of Pharonic Egypt, in: Ancient Egyptian Literature, History and Forms, Ed. A. Loprieno, Leiden 1996, 605-627.

R. B. Halbertsma, Scholars, Travellers and Trade: The Pioneer Years of the National Museum of Antiquities in Leiden 1818-1840, London-New York 2003.

W. R. Hamilton, Remarks on Several Parts of Turkey: Aegyptiaca, or Some account of the antient and modern State of Egypt, as obtained in the years 1801, 1802. Accompanied with etchings, from original drawings taken on the spot by the late Charles Hayes of the Royal Engineers, Volume 1, London 1809.

F. W. Hasluck, Stone Cults and Venerated Stones in the GraecoTurkish Area, BSA XXI, 1914, 62-83.

F. W. Hasluck, Christianity and Islam under the Sultans, New York I., II, (1929) 1973.

J. D. Hawkins, Inscriptions of the Iron Age: Part 1: Text, Introduction, Karatepe, Karkamis, Tell Ahmar, Maras, Malatya, Commagene. Part 2: Text, Amuq, Aleppo, Hama, Tabal, Assur Letters, Miscellaneous, Seals, Indices. Part 3: Plates, Berlin 2000.

M. F. S. Hervey, The Life, Correspondence \& Collections of Thomas Earl of Arundel, Cambridge 1921.

T. Hope, A Historical Essay on Architecture, Vol. 1, London 1835.

H. İnalcik, An Economic and Social History of the Ottoman Empire, Vol. 1., Cambridge 1997.

C. P. Jones, The Decree of Ilion in Honor of a King Antiochus, Greek, Roman, and Byzantine Studies 34, 1993, 74-93. 
Kelly 2012

Klonsky 1974

Knight 1866

Laborde 1838

Langbehn - Salama 2011

Leake 1824

Madrus - Mathers 1996

Makal 1954

Matthews 2015

McCabe 2008

Memorandum

Merivale 1874

Metropolitana 1845

Milstein - Rührdanz Schmitz 1999

Montfaucon 1761

Morritt 2010

Motraye 1723
C. Kelly, Political History: The Later Roman Empire, 11-23, in: M. Vessey (ed.), A Companion to Augustine, New York 2012.

M. Klonsky, The Fabulous Ego: Absolute Power in History, London 1974.

Ed. C. Knight, Arts and Sciences: Or, Fourth Division of "The English Encyclopedia", Vol. I, Bradbury, London 1866.

L. E. S. J. Laborde, Voyage de l'Asie Mineure par Alexandre de Laborde, Becker, Hall, et L. de Laborde, rédigé et publié par Léon de Laborde, Paris 1838.

V. Langbehn - M. Salama, German Colonialism: Race, the Holocaust, and Postwar Germany, 2011.

W. M. Leake, Journal of a tour in Asia Minor, with comparative remarks on the ancient and modern geography of that country, London 1824.

The Book of the Thousand Nights and One Night, J. C. Madrus - P. Mathers, Vols I-IV, London-New York 1996.

M. Makal, Memleketin Sahipleri, İstanbul 1954.

J. Matthews, The Notitia Urbis Constantinoplitanae, 81-115 Ed. L. Grig - G. Kelly, Two Romes: Rome and Constantinople in Late Antiquity, Oxford 2015.

I. B. McCabe, Orientalism in Early Modern France: Eurasian Trade, Exoticism, and the Ancien Régime, Berg, Oxford-New York 2008.

Memorandum on the subject of the Earl of Elgin's pursuits in Greece, London 1815.

C. Merivale, Augusti rerum a se gestarum indicem cum Graeca metaphrasi edidit Theodorus Bergk, (Leipzig 1873), The Academy and Literature, No. 95, Feb. 28, 1874, 234-235.

Encyclopaedia Metropolitana: Eds. E. Smedley - H. J. Rose - H. J. Rose, Vol. XIV, Miscellaneous and Lexicographical, Vol. I. "Arundelian Marbles," London 1845.

R. Milstein - K. Rührdanz - B. Schmitz, Stories of the Prophets: Illustrated Manuscripts of Qiṣaș al-anbiyā', Mazda, Costa Mesa, CA 1999.

R. P. Dom Bernard de Montfaucon, sur des recherches a faire dans le voyage du Constantinople \& du Levant (Mercure de France, janvier 1743), 151-166, in Nouveau choix de pièces tirées des anciens Mercures, et des autres journaux par M. De la Place, Tome 68. Paris 1761.

R. D. Morritt, Stones that speak, Cambridge 2010.

A. De La Mottraye, Travels through Europe, Asia, and into parts of Africa with proper cuts and maps containing: A great variety of Geographical, Topographical and Political Observations on those 
Museum 1850

Olivier 1802

Özel 2010

Panciera 2012

Payne Knight 1791

Peacham 1962

PSRL I

Ramsay 1918

Rees 1819

Rosenstein 2009

Sainsbury 1859

Sale et al. 1765

Sandwich 1807 parts of the World: especially on Italy, Turky (sic.), Greece, Crim and Noghaian Tartaries, Circassia, Sweden and Lapland. A curious collection of things particularly rare, in both Nature and Antiquity; such as remains of antient Cities and Colonies, Inscriptions, Idols, Medals, Minerals, etc. I, London 1723.

D. M. Masson, The British Museum, Historical and Descriptive, W. and R. Chambers, Edinburgh 1850.

G. A. Olivier, Travels in the Ottoman empire, Egypt, and Persia, undertaken by order of the government of France, during the first six years of the Republic. Transl. Vol.I, II [in 1], Trans. (1800) London 1802.

S. Özel, Under the Turkish Blanket Legislation: The Recovery of Cultural Property Removed from Turkey, International Journal of Legal Information 38/2, Article 10 (2010) 177-184, 178. Available at: http://scholarship.law. cornell.edu/ijli/vol38/iss2/10. Accessed 1201-2015.

S. Panciera, What is an Inscription? Problems of Definition and Identity of an Historical Source, ZPE 183, 2012, 1-10.

R. Payne Knight, An Analytical Essay on the Greek Alphabet, London 1791.

H. Peacham, The Complete Gentleman: The Truth of Our Times, And, The Art of Living in London Ed. V. B. Heltzel, Folger Documents of Tudor and Stuart Civilisation, New York 1962.

The Present State of the Republic of Letters. For January, 1728, Vol. 1, printed for W. Innys and J. Innys, London 1728.

W. M. Ramsay, The Utilisation of Old Epigraphic Copies, JHS XXXVIII, 1918, 124-192.

A. Rees, The Cyclopaedia, Or Universal Dictionary of Arts, Sciences and Literature XXVII, Longman, Hurst, Rees, Orme and Brown, London 1819.

L. Rosenstein, Antiques: the History of an Idea, New York 2009.

W. N. Sainsbury, Original Unpublished Papers Illustrative of the Life of Sir Peter Paul Rubens: As an Artist and a Diplomatist. Preserved in H. M. State Paper Office. With an Appendix of Documents Respecting the Arundelian Collection; the Earl of Somerset's Collection; the Great Mantuan Collection; the Duke of Buckingham etc., London 1859.

G. Sale - G. Psalmanazar - A. Bower - G. Shelvocke - J. Swinton (edd.), The Modern Part of an Universal History, from the Earliest Account of Time, Vol. XLIII, London 1765.

J. Montague, Earl of Sandwich, A voyage Performed by the Late Earl of Sandwich Round the Mediterranean, in the Years 1738 and 1739. 
Sandy 1673

Sandys 1908

Sandys 1919

Saradi 1997

Selden 1726

Sevin 1802

Smith 1678

Smith 1707

Smith $1707 a$
Written by Himself To which are Prefixed Memoirs of the Noble Author's Life, Lackington 1807.

G. Sandy, Sandys Travels, Containing an History of the Original and Present State of the Turkish Empire ... the Mahometan Religion and Ceremonies: a Description Of Constantinople ... Also, of Greece ... of Aegypt ... a Voyage on the River Nylvs ... a Description of the Holy-Land; of the Jews ... and What Else Either of Antiquity, or Worth Observation. Lastly, Italy Described, and the Islands Adjoining ... Illustrated with Fifty Graven Maps and Figures, London (1615), 1673.

J. E. Sandys, A History of Classical Scholarship: From the Revival of Learning to the End of the Eighteenth Century in Italy, France, England and the Netherlands, Vol. II, Cambridge 1908.

J. E. Sandys, Latin Epigraphy: An Introduction to the Study of Latin Inscriptions, Cambridge 1919.

H. Saradi, The Use of Ancient Spolia in Byzantine Monuments: The Archaeological and Literary Evidence, International Journal of the Classical Tradition, Vol. 3, No. 4 (Spring, 1997), 395-423.

J. Selden, Jurisconsulti, Opera omnia, tam edita quam inedita. In tribus voluminibus. Collegit ac recensuit; vitam auctoris, praefationes, \& indices adjecit, David Wilkins. In quo continentur, De successionibus in bona defunctorum; \& de successionibus in pontificatum Ebraeorum. De diis Syris. Eutychii Ecclesiae suae origines. Uxor ebraica. Analecta anglo-britannica. Janus Anglorum. Dissertatio ad Fletam. Judicium de decem scriptoribus anglicanis. Mare clausum. Vindiciae de scriptione Maris clausi. Marmora Arundelliana. Notae in Eadmerum. Epistolae \& poemata. Vol. II, London 1726.

F. Sevin, Lettres sur Constantinople. Suivies de plusieurs lettres de m. Peysonnel et d'autres savans. On y a joint la Relation du consulat de $\mathrm{m}$. Anquetil à Surat [\&c. Ed. by A. Serieys] revu par l'abbé Bourlet de Vauxcelles, Paris An. X, 1802.

Dr. T. Smith, Remarks upon the Manners, Religion and Government of the Turks. Together with a Survey of the Seven Churches of Asia as they now lye in their Ruines: and a Brief Description of Constantinople, London 1678.

T. Smith, Historical Observations relating to Constantinople, 32-48, Miscellanea curiosa. Containing a collection of Curious Travels, Voyages and Natural Histories of Countries, as they have been delivered in to the Royal Society, Royal Society (Great Britain) Vol. III, London 1707.

T. Smith, An Account of the City of Prusa in Bithynia, and a continuation of the Historical Observations relating to Constantinople, 
Smith 1883

S.O.D. ${ }^{3} 1969$

Spon 1673

Spon 1678

St. Clair 1967

Stoneman 2010

Stubbs 1876

Taylor 2013

Tierney 1834

Tournefort 1741

Turks 2005

Tütüncü 2018

Twells 1740

Wallis Budge 1896

Walsh 1825

Warburton 1811
48-83, Miscellanea curiosa. Containing a collection of Curious Travels, Voyages and Natural Histories of Countries, as they have been delivered in to the Royal Society, Royal Society (Great Britain) Vol. III, London 1707.

C. Smith, Inscriptions from Rhodes, JHS 4, 1883, 136-141.

The Shorter Oxford Dictionary.

J. Spon, Recherche des Antiquités de la ville de Lyon, Lyon 1673.

J. Spon, G. Wheler, Voyage d'Italie, de Dalmatie, de Grèce et du Levant: fait és années 1675 \& 1676 par Jacob Spon \& George Wheler, 1678.

W. St. Clair, Lord Elgin and the Marbles, Oxford 1967.

R. Stoneman, Land of Lost Gods: The Search for Classical Greece, 2010.

Radulfi de Diceto decani Lundoniensis opera historica, The Historical Works of Master Ralph de Diceto, Dean of London Ed. R. Stubbs, Two Vols, Rolls Series, 68, Vol. II, London 1876.

B. J. Taylor, Sir Robert Ainslie, Domenico Sestini and Luigi Mayer: A Case of who went where, with Whom and When, Ch. 13, in, Ed. D. Fortenberry, Souvenirs and New Ideas: Travel and collecting in Egypt and the Near East, Oxford 2013.

Rev. M. A. Tierney, The Antiquities of Arundel: The peculiar privilege of its castle and Lordship; with an Abstract of the Lives of the Earls of Arundel, from the Conquest to this time, Vol. II, London 1834.

Tournefort A Voyage into the Levant performed by command of the late French King, (1717) Trans. John Ozell, Vol. III, London 1741.

Turks: A Journey of a Thousand Years, 600-1600, Exh. Cat., Ed. D. J. Roxburgh. Royal Academy of Arts (Great Britain), London 2005.

M. Tütüncü, Rodos'ta Türk Denizcilerinin Koruyucu (Tılsım) Taşı, Toplumsal Tarih, Şubat 2018, 13-17.

L. Twells, The theological Works of the Learned Dr. Pocock, containing his porta Mosis and English commentaries on Hosea, Joel, Micah and Malachi: With life and writings of the author by Leonard Twells, Vol. 1., London 1740.

E. A. Wallis Budge, The Life and Exploits of Alexander the Great: Being a Series of Translations of the Ethiopic Histories of Alexander by the Pseudo-Callistenes and other Writers, J. Clay and Sons, Cambridge 1896.

R. Walsh, Account of the Levant Company, London 1825.

The Works of the Right Reverend William Warburton, D. D., Lord Bishop of Gloucester: A New Edition in Twelve Volumes, Vol. IX, 
Weber 1812

Werner 2011

Wheler 1682

Wittman - Phillips 1803

Wright 2004

Wroth 1893

Yürekli 2016

El-Zein 2009

London 1811.

H. Weber, Tales of The East; comprising The Most Popular Romances of Oriental Origin; and the best imitations by European authors: with new translations, and additional tales, never before published, Vol. II, Edinburgh 1812.

M. Werner, Multiple Antiquities-Multiple Modernities: Ancient Histories in Nineteenth Century European Cultures, Frankfurt-New York 2011.

George Wheler Esq, Journey into Greece; In Company of Dr. Spon of Lyons, In 6 Books with Variety of Sculptures, London 1682.

W. Wittman - Sir R. Phillips, Travels in Turkey, Asia-Minor, Syria, and Across the Desert Into Egypt During the Years 1799, 1800, and 1801, in Company with the Turkish Army, and the British Military Mission: To which are Annexed, Observations on the Plague and on the Diseases Prevalent in Turkey, and a Meteorological Journal, London 1803.

D. G. Wright, Review of E. W. Bodnar, C. Foss, Cyriac of Ancona: Later Travels, 2003, Bryn Mawr Classical Review 2004.07.69 http://bmcr.brynmawr.edu/2004/2004-07-69.html.

W. W. Wroth, Leake, William Martin, in: Ed. S. Leslie, DNB 32, London 1893, 323-324.

Z. Yürekli, Architecture and Hagiography in the Ottoman Empire: The Politics of Bektashi Shrines in the Classical Age, London 2016.

A. El-Zein, Islam, Arabs, and the Intelligent World of the Jinn, 2009.

\section{9. yüzyılın başlangıcına kadar Küçük Asya'daki erken dönem antika meraklıları hakkında Özet}

Bu yazı 1400 yılından 1800 yılına kadarki dönem ile, şüphesiz başka isimler de mevcut olmak üzere, antik metinlerin transkripsiyonlarını da yapmış olan 60'tan fazla Avrupalı'nın antik eserlere yönelik etkinliklerini kapsamaktadır. Hikâye ayrıca, onların malzemeyi bulan ve zaman zaman da yazıtların Küçük Asya'dan götürülmesini sağlayan aracılarını, Osmanlı tanıdıklarını, rehberlerini, köylüleri ve Yunan rahiplerini de içermektedir. Aynı zamanda, bununla bağlantılı olarak bu antika meraklıları tarafından "mermer", antik elyazmaları, madalyonlar-sikkeler, yazılı değerli taşlar ve diğer yazılı materyallerin toplanması da konuya dahil edilmiştir. Bu malzemelerin bir kısmı Küçük Asya'dan alındığında taşıma esnasında denizde kaybolurken, bazı antik yazitlar da hasar görmüş, Avrupa'daki savaşlar esnasında kaybolmuş ya da yok edilmiştir. Yazıtlara ilişkin en erken çalışmalar Ciriaco de Pizzicolli’nin 15. yüzyıldaki transkripsiyonları ve Pierre Belon tarafından 1546-9 yılları arasında yapılan birkaç yazıt transkripsiyonudur. Fakat Avrupalı akademisyenler Küçük Asya'daki günümüze ulaşan antik epigrafik belgelerin önemini, Agria (Eger) Piskopos'u Antonius Verantius'un Res Gestae Divi Augusti transkripsiyonu, aynı yazıtın 1555 yılında Busbecq'in Ankara'daki hizmetkârları tarafından yapılan kopyasının yayılması ve bunun 1579 yılından itibaren sürekli yayımlanması sonrasında kavramışlardır. 17. yüzyılın baş- 
larından itibaren sayısı gittikçe artan Avrupalı antika meraklıları, büyük kısmı Troas, Ege'nin kıyı bölgeleri ve Küçük Asya'nın temel ticaret yolları boyunca görülebilen yazıtların kayıt altına alma görevini de üstlenmişlerdir. Söz konusu antik yazıtlara dair kayıtlı Osmanlı görüşlerinin çeşitliliği, yapılan transkripsiyonlar, bu yazıtların zaman zaman berat sahibi Avrupalılarca götürülmeleri; metindeki ya da metnin kontekstindeki sorun, matbu baskı ile birlikte gelen yazıt yayınında oluşan durumlar; epigrafik estampajlardan önceki yüzyıllarda transkripsiyonu gerçekleştirilen yazıtlarda görülen uydurmalar ve hatalara dair bazı örnekler dikkate alınmıştır.

Anahtar Kelimeler: Küçük Asya, antik yazarlar, kolleksiyon, Osmanlı berat sahipleri, transkripsiyonlar.

\section{On early antiquarians in Asia Minor to the start of the $19^{\text {th }}$ century}

Abstract

This paper covers a period of 400 years, from 1400 to 1800 , and the antiquarian activities of more than 60 named Europeans, there are doubtless others, who were involved in transcribing, and at times, through their agents and Ottoman associates, guides, villagers and Greek priests, those who related the position and at times enabled the physical removal of ancient inscriptions from Asia Minor; as well as the associated antiquarian collecting of "marbles," ancient manuscripts, medals-coins, inscribed gem-stones and other inscription bearing materials. Some of this material was lost at sea, while some ancient inscriptions brought from Asia Minor were damaged, lost or destroyed in warfare in Europe. Following Ciriaco de Pizzicolli's transcriptions in the $15^{\text {th }} \mathrm{c}$. and the few inscriptions transcribed by Pierre Belon in 1546-9, it seems to have been the Bishop of Agria (Eger), Antonius Verantius's transcription of the Res Gestae Divi Augusti and the copy made by Busbecq's servants in Ankara in 1555 which, when circulated and then published, underlined to European scholars the importance of the surviving ancient epigraphic record in Asia Minor. From the start of the $17^{\text {th }} \mathrm{c}$. an increasing number of educated European antiquarians undertook the recording of the surviving visible inscriptions, largely in coastal regions and along the major trade routes of Asia Minor. Note is taken of the variety of recorded Ottoman views concerning these ancient inscriptions, of their transcription and, at times, their removal by European berat holders; together with some examples of the inaccuracies of the transcriptions of inscriptions that were made.

Keywords: Asia Minor, Ancient inscriptions, collecting, Ottoman berat holders, transcriptions. 